\title{
Mistaken Gifts after Pitt v Holt
}

\author{
Birke Häcker
}

\begin{abstract}
In Pitt v Holt [2013] UKSC 26, the Supreme Court ruled on the conditions under which a voluntary deed can be set aside for spontaneous mistake. This paper explores the ramifications of the decision for the law of mistaken gifts more generally. It examines the suggestion that Pitt v Holt establishes (or confirms the existence of) a special restitutionary regime for all gift transactions, as well as the alternative interpretation which regards Pitt $v$ Holt as concerning only the equitable remedy of rescission, leaving common law claims unaffected. Drawing on the experience of other legal systems, the paper argues that English law should not develop a special law of gifts nor cement the dividing line between common law and equity, but should instead use Pitt $v$ Holt as a trigger and catalyst for rationalizing the ordinary law of unjust enrichment.
\end{abstract}

\section{Introduction}

A recent Supreme Court decision puts into sharp focus a question which has vexed English lawyers for some time. When can a donor recover a gift mistakenly made? In Pitt $v$ Holt, ${ }^{1}$ the Supreme Court held that a voluntary deed could be set aside only if there was a 'causative mistake of sufficient gravity', such that it would be 'unconscionable' to leave the mistaken disposition uncorrected. ${ }^{2}$ However, the remit and broader implications of the ruling are not entirely clear. It is open to different interpretations, each premised on certain conceptual assumptions about the nature of gifts, their proper place within the evolving law of unjust enrichment, and the structure of the remedial framework surrounding them. The aim of this paper is to explore these issues with an eye to potential future developments of the law.

To set the scene, picture a happy couple sitting in a restaurant on Valentine's Day. Once the champagne has been served, the man-let's call him John Smith-makes a gift of a

* Senior Research Fellow, Max Planck Institute for Tax Law and Public Finance, Munich, birke.haecker@tax.mpg.de, and Fellow of All Souls College, Oxford, birke.haecker@law.ox.ac.uk. This paper is based on a CLP lecture delivered on 13 February 2014, on the eve of Valentine's Day. I am grateful to UCL for inviting me, to all those who commented on earlier drafts of this and an unpublished predecessor paper entitled 'Mistaken Gifts', to the participants in the discussion following the CLP lecture, and to the Rt Hon Sir Timothy Lloyd for chairing the session.

${ }^{1}$ Pitt v Holt (consolidated appeal with Futter v Futter) [2013] UKSC 26, [2013] 2 AC 108.

2 ibid [122]-[126]. See text to notes 35-37. 
beautiful necklace to his girlfriend to thank her for sticking by him during a very difficult recent phase of his life. He subsequently discovers that she has in fact been cheating on him ever since last year's Christmas party at the office. Enraged and disappointed by her infidelity, John demands to have the necklace back. Can he do so, or should he be able to? That is the kind of question this paper seeks to address. The example also demarcates the limits of the present inquiry, which will only be concerned with inter vivos transfers, leaving the specific problems surrounding testamentary gifts to one side. ${ }^{3}$

The paper is structured as follows. It begins by briefly sketching different strands or 'tests' for the recovery of mistaken gifts within the case law preceding Pitt $v$ Holt, before turning to that decision itself. What conclusions can we draw from the enquiry envisaged by the Supreme Court? One possible interpretation is that 'gifts' need to be seen as a special class of transaction which deserve a greater measure of protection against unwinding than the default rules on restitution for unjust enrichment can offer. It will be argued that while such an interpretation is conceptually feasible, it would require English law to develop a much more sophisticated theory of gifts. Moreover, the strong element of judicial discretion inherent in the Supreme Court's criteria for 'setting aside' a voluntary disposition would make such an approach difficult to operate in practice. An alternative view, discussed thereafter, is that Pitt v Holt pertains only to the equitable remedy of rescission and has no repercussions beyond that. After throwing a side-glance at how other jurisdictions (particularly Germany) handle the problem of mistaken gifts, the paper will seek to show that the best way forward for English law is to integrate their treatment into the ordinary law of restitution for unjust enrichment. Properly applied and appropriately refined in the light of Pitt $v$ Holt , the simple causative mistake test can actually accommodate most of the concerns which tend to drive the call for an additional hurdle of 'sufficient gravity'.

\section{Preceding Case Law}

\footnotetext{
${ }^{3}$ As English law stands, wills may be rectified under the Administration of Justice Act 1982, s 20, if the testator's intention has been misrecorded, but it seems that testamentary dispositions cannot normally be set aside for mistakes occurring in the process of forming the intention.
} 
Note: This is the manuscript of an article published in (2014) 67 Current Legal Problems 333-372, as submitted to and accepted for publication by the volume editor(s) on 11 June 2014.

It does not contain any later editorial amendments or corrections made during the proofing process. Please use for preliminary reference only and cite the final published version with the appropriate pagination.

Prior to Pitt $v$ Holt, there were essentially three different approaches towards mistaken gifts emerging from the case law. Though the criteria differed in detail and not all decisions can be unambiguously allocated to one or the other, it is convenient for exposition purposes to set them out in their sharpest contours as a backdrop for the discussion which follows.

The first approach may be labelled the pure 'causative mistake test'. It goes back to the seminal exposition of the modern law of unjust enrichment as applied to mistaken payment cases (actions for money had and received) by Robert Goff $\mathbf{J}$ in Barclays Bank Ltd $v$ WJ Simms Son \& Cooke (Southern) Ltd. ${ }^{4}$ Freeing English law from the 'supposed liability' rule, ${ }^{5}$ he said:

(1) If a person pays money to another under a mistake of fact which causes him to make the payment, he is prima facie entitled to recover it as money paid under a mistake of fact. (2) His claim may however fail if (a) the payer intends that the payee shall have the money in all events, whether the fact be true or false, or is deemed in law so to intend; or (b) the payment is made for good consideration, in particular if the money is paid to discharge, and does discharge a debt owed to the payee ... by the payer or by a third party by whom he is authorised to discharge the debt; or (c) the payee has changed his position in good faith, or is deemed in law to have done so. ${ }^{6}$

The subsequent abolition of the old 'mistake of law bar' in Kleinwort Benson Ltd $v$ Lincoln City Council, ${ }^{7}$ and the final recognition of the change of position defence in Lipkin Gorman (a firm) v Karpnale Ltd, ${ }^{8}$ facilitated the argument that gifts or their value should be recoverable for any causative mistake, whether of fact or law, subject only to adequately protecting the donees' reliance on the security of their receipt. In fact, this conclusion was expressly drawn by Brennan $\mathrm{J}$ in the Australian High Court case which authoritatively adopted the causative mistake test in that jurisdiction. ${ }^{9}$ He stated that he saw no reason why, if a payment

${ }^{4}$ Barclays Bank Ltd v WJ Simms Son \& Cooke (Southern) Ltd [1980] QB 677.

5 According to the 'supposed liability' rule, the mistake had to relate to a specific fact which, if true, would have made the payer liable to pay and would have provided an entitlement for the recipient to retain the money, see eg Kelly v Solari (1841) 9 Mees \& W 54, 58, 152 ER 24, 26, per Parke B; Aiken v Short (1856) 1 Hurl \& N 210 , 215, 156 ER 1180, 1182, per Bramwell B.

${ }^{6}$ Barclays Bank v Simms (n 4) 695.

${ }^{7}$ Kleinwort Benson Ltd v Lincoln City Council [1998] UKHL 38, [1999] 2 AC 349.

${ }^{8}$ Lipkin Gorman (a firm) v Karpnale Ltd [1988] UKHL 12, [1991] 2 AC 548.

${ }^{9}$ David Securities Pty Ltd v Commonwealth Bank of Australia [1992] HCA 48, 175 CLR 353. 
was made by way of gift, the donor should not be entitled to restitution if he 'would not have paid the money had [he] known all the relevant circumstances, both legal and factual'. ${ }^{10}$ Although only a small number of decisions have openly committed themselves to applying the pure causative mistake test to gifts, ${ }^{11}$ there is case law both before and after Simms which is arguably compatible with it. ${ }^{12}$

The second and third approaches were markedly more restrictive. Some decisions suggested that, in order to warrant restitutionary relief, the donor's mistake must have been induced through a misrepresentation made by the other party, at least if the mistake relates to the donor's reason for making the gift. ${ }^{13}$ This 'induced mistake test' is perhaps best illustrated by a dictum from Lord Scott's speech in Deutsche Morgan Grenfell Group plc v Inland Revenue Commissioners. ${ }^{14}$ Discussing the example of a man who makes of gift of $£ 1,000$ to another mistakenly believing the donee to be impecunious when in fact the recipient is a person of substantial wealth, his Lordship observed:

My present opinion is that unless there were some reason, such as a misrepresentation by [the donee] to enable the gift to be set aside, the mistake made by [the donor] would not suffice, notwithstanding that the payment had not been made pursuant to any legal obligation and that but for the mistake it would not have been made. ${ }^{15}$

10 ibid 392-93.

11 Fender v National Westminster Bank plc [2008] EWHC 2242 (Ch); from the Isle of Man Clarkson v Barclays Private Bank and Trust (Isle of Man) Ltd [2007] WTLR 1703.

${ }^{12}$ Lady Hood of Avalon v Mackinnon [1909] 1 Ch 476; Re Ellis's Settlement, Ellis v Ellis (1909) 26 TLR 166 (Ch D). Other decisions which may be fitted into this category as far as their outcome is concerned, although they employ the language of 'seriousness' or 'fundamentality', are Ogden v Trustees of the RHS Griffiths 2003 Settlement [2008] EWHC 118 (Ch), [2009] Ch 162, and from New Zealand University of Canterbury v AttorneyGeneral [1995] NZLR 78.

${ }^{13}$ See Wilson v Thornbury (1875) LR 10 Ch App 239, esp 248-49, per James LJ, suggesting that only a fraudulent misrepresentation would suffice; Re Glubb, Bamfield v Rogers [1900] 1 Ch 354 (CA), esp 361-62, per Lindley MR, recognizing that an 'innocent' (ie non-fraudulent) misrepresentation is enough to make a gift voidable in equity.

\footnotetext{
${ }^{14}$ Deutsche Morgan Grenfell Group plc v Inland Revenue Commissioners [2006] UKHL 49, [2007] 1 AC 558.

15 ibid [87].
} 
Such an 'induced mistake test' is compatible - and was indeed often combined with - a third test which could be described as a 'serious mistake test'. This goes back to a statement by Lindley LJ in Ogilvie v Littleboy. ${ }^{16}$ He set out the relevant principles as follows:

\begin{abstract}
Gifts cannot be revoked, nor can deeds of gift be set aside, simply because the donors wish they had not made them and would like to have back the property given. Where there is no fraud, no undue influence, no fiduciary relation between donor and donee, ${ }^{[17]}$ no mistake induced by those who derive any benefit by it, a gift, whether by mere delivery or by deed, is binding on the donor. [...] In the absence of all such circumstances of suspicion a donor can only obtain back property which he has given away by showing that he was under some mistake of so serious a character as to render it unjust on the part of the donee to retain the property given to him. ${ }^{18}$
\end{abstract}

There were several other versions of the 'serious mistake test', deriving mainly from decisions where Ogilvie v Littleboy was either not cited or not considered. They, too, made everything turn on the character or nature of the donor's mistake rather than looking at the way in which it was brought about. For example, the Court of Appeal in the common law case of Morgan v Ashcroft suggested that a mistake made in the context of a voluntary payment was only relevant if it was 'fundamental' enough to 'negative the intention' to transfer property. ${ }^{19}$ On the equity side, the judgment by Millett $\mathrm{J}$ in Gibbon $v$ Mitchell had established itself as authority for the proposition that a voluntary deed would be set aside for mistake only if the mistake was 'as to the effect of the transaction itself and not merely as to its consequences or the advantages to be gained by entering into it' ${ }^{20}$

${ }^{16}$ Ogilvie v Littleboy (1897) 13 TLR 399 (CA), affirmed sub nom Ogilvie v Allen (1899) 15 TLR 294 (HL).

${ }^{17}$ We have plenty of case law confirming that gifts may be set aside for undue influence, especially (but not only) where the donee stands in a fiduciary relationship towards the donor. The locus classicus for the doctrine of undue influence as applied to gifts is Allcard $v$ Skinner (1887) $36 \mathrm{Ch}$ D 145 (Ch D and CA). Note that there is now even a case holding that the doctrine of unconscionable bargains or 'unconscionable transactions' may also operate in the gift context: Evans v Lloyd [2013] EWHC 1725 (Ch).

${ }^{18}$ Ogilvie v Littleboy (CA) (n 16) 400 (emphasis added). A case nominally applying this standard was Ogden v Trustees of the RHS Griffiths 2003 Settlement (n 12).

${ }^{19}$ Morgan v Ashcroft [1938] 1 KB 49 (CA), esp 65-67, per Sir Wilfrid Greene MR, and 73-74, 77, per Scott LJ. This language of 'fundamentality' was also invoked in the New Zealand case of University of Canterbury $v$ Attorney-General (n 12), though it is hard to regard the donor's misapprehension in that case as negativing his intention to pay.

${ }^{20}$ Gibbon v Mitchell [1990] 1 WLR 1304, 1309, [1990] 3 All ER 338, 343 (Ch D). 


\section{The Decision in Pitt v Holt}

The sad story behind Pitt v Holt began in 1990, when Mr Pitt was so seriously injured in a car accident that he remained mentally incapacitated for the rest of his life. He received a substantial amount of compensation (consisting of a lump sum payment and an annuity), which his wife, who had been appointed as his receiver under the Mental Health Act 1983, wanted to invest as prudently as possible. Mrs Pitt therefore sought legal and financial advice and was told that the best course was to create a discretionary settlement for the benefit of Mr Pitt as well as Mrs Pitt and their children. Unfortunately, the advisers she retained had given thought only to income tax and capital gains tax, and had failed to consider potential inheritance tax implications. They had thus failed to spot that the Pitts could easily have availed themselves of an exemption from inheritance tax under a statutory provision specifically designed to privilege discretionary trusts for disabled persons. ${ }^{21}$ As a result, the settlement (approved by the Court of Protection) was drafted in a way that made a large amount of tax fall due on Mr Pitt's death in 2007. In order to escape this liability, Mrs Pitt sought to have both the deed establishing it and the assignment of the annuity into it avoided. Her claim was nominally directed against Mr Holt, one of the other trustees of the 'Derek Pitt Special Needs Trust', but the only defendant actually fighting the case was the Revenue, who had been joined to the proceedings.

Mrs Pitt advanced two main lines of argument. The first, based on what is (or used to be) known as the rule in Re Hastings-Bass, ${ }^{22}$ is beyond the remit of this paper. Suffice it to note that she failed on this count because both the Court of Appeal and the Supreme Court regarded the supposed rule as far too widely stated and therefore severely curtailed the conditions under which decisions of trustees and other fiduciaries may be impugned for failing to take into

\footnotetext{
${ }^{21}$ In accordance with the Inheritance Tax Act 1984, s 89, this would have required the insertion of a clause stipulating that at least half of the settled property applied during Mr Pitt's lifetime was to be applied for his benefit.

${ }^{22}$ Re Hastings-Bass (Deceased) [1974] EWCA Civ 13, [1975] Ch 25.
} 
account all relevant considerations. ${ }^{23}$ Mrs Pitt's second ground for seeking annulment of the instruments she had executed was that she had made an operative mistake when setting up the discretionary trust. This is the aspect of the case with which we are here concerned.

At first instance, her claim based on mistake failed. ${ }^{24}$ The trial judge, Robert Englehart QC, found that Mrs Pitt had simply not thought about inheritance tax and so could not be said to have been mistaken in this regard. ${ }^{25}$ The Court of Appeal disagreed, with the leading judgment given by Lloyd LJ. ${ }^{26}$ The Court held that Mrs Pitt had made a mistake in wrongly believing that the settlement proposed by her advisers had no adverse tax implications. ${ }^{27}$ Yet that was only the first hurdle. In addition to having made a causative mistake, the Court of Appeal required Mrs Pitt to show that her mistake was 'sufficiently serious' according to the test laid down in Ogilvie $v$ Littleboy, ${ }^{28}$ and-further - that it was either as to the legal effect of the transaction or to an existing fact basic to it, ${ }^{29}$ drawing on Gibbon $v$ Mitchell ${ }^{30}$ and Lady Hood of Avalon $v$ Mackinnon $^{31}$. The Court found that although Mrs Pitt's mistake was of sufficient gravity, it concerned only the tax consequences of the settlement and would therefore not qualify for relief. $^{32}$

${ }^{23}$ This aspect of Pitt $v$ Holt and Futter v Futter is discussed by PS Davies and G Virgo, 'Relieving Trustees' Mistakes' [2013] RLR 74, 75-79; F Ng, 'Pitt v Holt and Futter v Futter: the Rule in Hastings-Bass, Mistake, and Tax Avoidance' [2013] BTR 566, 569-73; R Nolan, 'Fiduciaries and their Flawed Decisions' (2013) 129 LQR 469, 470-72; R Wilson, 'The Rule in Re Hastings-Bass: Futter v Futter; Pitt v HMRC-Further Thoughts' [2014] PCB 20.

${ }^{24}$ Pitt v Holt [2010] EWHC 45 (Ch), [2010] 1 WLR 1199, [2010] 2 All ER 774, [49]-[54]. It succeeded on the Re Hastings-Bass line of argument: see esp [33]-[48].

${ }^{25} \mathrm{He}$ said that 'if someone does not apply his mind to a point at all, it is difficult to say that there has been some real mistake about the point' (ibid [50]), adding that, even if Mrs Pitt had made a mistake, it was only as to the consequences or advantages of the transaction, not one as to effect (ibid [53]).

${ }^{26}$ Pitt v Holt (consolidated appeal with Futter v Futter) [2011] EWCA Civ 197, [2012] Ch 132, esp [164][220].

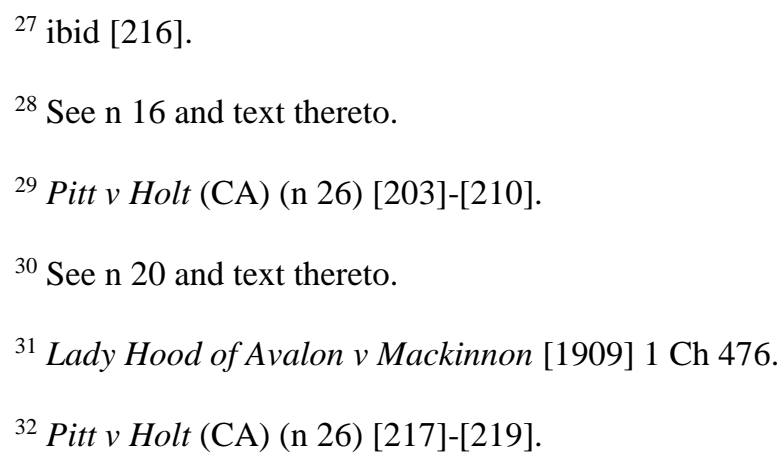


In the Supreme Court, the case was heard by a panel of seven, but there was only a single judgment, delivered by Lord Walker. ${ }^{33}$ He agreed that Mrs Pitt had been mistaken when setting up the trust. However, of the three substantive hurdles identified in the Court of Appeal, the Supreme Court accepted only two. It rejected the test propounded in Gibbon v Mitchell as being too narrow, or if the 'effects' category was further widened, as not adding anything significant to the seriousness test derived from Ogilvie v Littleboy. ${ }^{34}$ Accordingly, Lord Walker said that 'the true requirement is simply for there to be a causative mistake of sufficient gravity', ${ }^{35}$ with the 'gravity of the causative mistake to be assessed in terms of injustice—or, to use equity's cumbersome but familiar term, unconscionableness' ${ }^{36}$ As regards the latter, he explained that '[t]he injustice (or unfairness or unconscionableness) of leaving a mistaken disposition uncorrected must be evaluated objectively, but with an intense focus ... on the facts of the particular case'. ${ }^{37}$

In Pitt $v$ Holt, having considered all the relevant facts, the Supreme Court thought that Mrs Pitt's tax mistake was indeed sufficiently serious. Because relief is ultimately portrayed as being a matter of judicial discretion, ${ }^{38}$ it is hard to pinpoint the decisive factor, but what seems to have weighed heavily on their Lordships' minds was that the Pitts could easily have availed themselves of the tax advantage they had unwittingly forgone. Not making use of it was, in Lord Walker's words, 'a serious matter for Mrs Pitt, both as her husband's receiver and on her own account as his wife and carer and as the eventual beneficiary of his estate'. ${ }^{39}$

\section{A Special Law of Gifts?}

\footnotetext{
${ }^{33}$ The discussion of the mistake limb of the case is to be found in Pitt v Holt (SC) (n 1) [99]-[142].

34 ibid [122].

35 ibid.

36 ibid [124].

37 ibid [126].

${ }^{38}$ See text following n 60.

${ }^{39}$ Pitt $v$ Holt (SC) (n 1) [133]. As this statement also indicates, Mrs Pitt was affected in various roles. The Supreme Court did no make specify which role, if any, was to be accorded primary relevance, but it is submitted that it should have been the first of the three. For a critical comment, arguing that Mrs Pitt did not actually execute the documents in her receiver capacity and that the real mistake lay with the Master of the Court of Protection, see D Rees, 'Whose Mistake is it Anyway?' [2014] PCB 149, 152-53.
} 
When asking oneself what Pitt $v$ Holt might mean for the position of someone like John Smith in the example given earlier, the first interpretation that springs up is that the Supreme Court has sought to formulate (or perhaps re-formulate) a rule peculiar to the law of gifts and comparable transactions. ${ }^{40}$ That line of reasoning runs as follows:

While the starting point in all mistaken transfer cases is the principle formulated in Barclays Bank v Simms, ${ }^{41}$ namely that any causative mistake counts and yields a right to recover what one has transferred or its value, there are modifications to be made to this principle where we are concerned with a 'voluntary disposition' such as a gift. By contrast to the mistaken payer in a typical liability mistake scenario, who has rendered a performance that was not owing to the recipient, a mistaken donor does not deserve to recover unless his mistake was sufficiently serious as well as being causative. This is because the law affords special protection to performances rendered by way of gift.

Conceptually, it amounts to saying that 'gift' is a legal basis or justification for the transfer, in the same way that a valid contract is prima facie a justification for the recipient retaining what she has received in pursuance of it. If the transferor wants to recover, he has to invalidate the gift first. This is how one could understand the references to 'rescission' in Pitt v Holt and in the various gift cases discussed by Lord Walker. Although gifts (thus conceived) will be more vulnerable than contracts to rescission, because they are not make in the commercial sphere and therefore do not deserve as much protection as proper bargains, ${ }^{42}$ something more than a unilateral mistake plain and simple is needed.

Such an interpretation of Pitt $v$ Holt is perfectly coherent in its own right, and it actually aligns with a view of mistaken gifts that has been put forward for some time, most notably perhaps by Professor Tang Hang $\mathrm{Wu} .{ }^{43}$ Drawing, inter alia, on the seminal anthropological

\footnotetext{
${ }^{40}$ See only the excellent case note by S Watterson, 'Reversing mistaken voluntary dispositions' (2013) 72 CLJ 501, regarding this interpretation as the 'most plausible' one (at 504), while setting out a number of possible alternatives and observing with some regret that everything remains 'highly speculative'.

${ }^{41}$ See $\mathrm{n} 4$ and text thereto.

${ }^{42}$ That point actually arose for discussion in Pitt $v$ Holt: see notes $182-183$ and text thereto.

${ }^{43}$ HW Tang, 'Restitution for Mistaken Gifts' (2004) 20 JCL 1. See also S Meier, 'Unjust Factors and Legal Grounds' in D Johnston and R Zimmermann (eds), Unjustified Enrichment: Key Issues in Comparative Perspective (CUP 2002) 37, 43-54.
} 
study by Marcel Mauss, ${ }^{44}$ he sees gifts as mechanisms of informal social exchange operating in the 'moral economy' in a similar way as contracts operate in the ordinary commercial world. ${ }^{45}$ This leads him to argue:

\begin{abstract}
Just as it is important to protect the market economy from being subverted by the law of restitution by recognizing the sanctity of contracts, it is equally essential to protect the moral economy by defending the completed gift from an overzealous application of the law of restitution. ${ }^{46}$
\end{abstract}

If that is what Pitt $v$ Holt is out to achieve and, more importantly, if it is how judges in future cases come to regard Pitt $v$ Holt, then English law will be faced with two main challenges over the next decades. One relates to the definition of a 'gift', the other to the application of the seriousness test as set out in Pitt $v$ Holt.

\title{
Defining the Scope of Protected Transactions
}

The first challenge entailed by the above-mentioned interpretation of Pitt $v$ Holt is that English lawyers will have to get a much clearer idea about what they mean by 'gift' or 'voluntary disposition', starting with the question whether these terms are actually synonymous or not. In case it be thought that this exercise cannot be very difficult, just pause for a moment and consider Pitt $v$ Holt itself. There we had a discretionary trust into which Mr Pitt's lump sum damages and the annuity were put. The beneficiaries were Mr Pitt, Mrs Pitt, and their children, although the latter could not receive any distributions without the consent of the Court of Protection. ${ }^{47}$ Without going further into the details of the settlement, it is evident that there was a 'gift' only in a tenuous sense of the word, which is probably why the whole argument and the judgments revolved around the term 'voluntary disposition' instead. Gifts may well be a sub- or side-category of voluntary dispositions, but because the present paper examines how Pitt v Holt impacts specifically on 'mistaken gifts' (as conventionally understood), and because these also featured prominently in the Supreme Court's reasoning, the discussion which follows will treat

\footnotetext{
${ }^{44}$ M Mauss, The Gift: Forms and Functions of Exchange in Archaic Societies (Cohen \& West 1966).

45 Tang (n 43) 22-25.

46 ibid 24.

${ }^{47}$ cf Pitt v Holt (Ch) (n 24) [11].
} 
Note: This is the manuscript of an article published in (2014) 67 Current Legal Problems 333-372, as submitted to and accepted for publication by the volume editor(s) on 11 June 2014.

It does not contain any later editorial amendments or corrections made during the proofing process. Please use for preliminary reference only and cite the final published version with the appropriate pagination.

'gift' as the central case and refer to other kinds of 'voluntary disposition' only by way of addendum.

Looking at the relevant case law and literature, it quickly becomes apparent that English law does not yet have a fully-blown theory of gifts. In textbooks on (personal) property law, one often finds 'transfers by way of gift' being listed alongside 'sale', as if 'gift' was somehow a mode of transferring title. ${ }^{48}$ What is meant, of course, is that title to chattels usually passes by delivery (ie physical handing over coupled with the relevant intention) where there is no contract enabling it to be transferred by consent alone, ${ }^{49}$ and that informal gifts are the most conspicuous example of this happening. ${ }^{50}$ At other times, or for other purposes, judges and authors distinguish between gifts made at common law (often called 'outright gifts') and gifts effected in equity by means of a trust. ${ }^{51}$ The general impression one gets is that the notion of 'gift' is a shimmering concept whose meaning and content fluctuate depending on context.

Compare this to contract law, where we have lots of detailed rules and principles emerging from a large body of cases that help us delineate quite clearly the sphere of bargains which attract the law's special treatment. Suffice it to mention all the rules about offer and acceptance, intention to create legal relations, and of course the doctrine of consideration. The law of gifts, by contrast, is markedly less developed. This may be illustrated by raising just a

${ }^{48}$ See eg ELG Tyler and N Palmer, Crossley Vaines on Personal Property (5th edn, Butterworths 1973) 299366; AP Bell, Modern Law of Personal Property in England and Ireland (Butterworths 1989) 221-60; FH Lawson and B Rudden, The Law of Property (3rd edn, OUP 2002) 53-62; M Bridge, L Gulliver, G McMeel, and S Worthington, The Law of Personal Property (Sweet \& Maxwell 2013) paras 8-016 to 8-030, discussing 'gifts' under the main heading 'Acquisition and Divestment of Interests by Consent at Common Law', though the text in paras 8-003 and 8-025 indicates that the authors actually regard delivery of possession as the relevant mode of acquisition.

${ }^{49}$ See the Sale of Goods Act 1979, ss 17-18. It is not entirely clear whether and how far the so-called 'solo consenu' principle also applies outside sale, eg to contracts of barter and exchange.

50 This is explained in admirably clear terms by D Sheehan, The Principles of Personal Property Law (Hart Publishing 2011) 33-56, who sub-divides the chapter dealing with the 'Transfer of Legal Title to Tangibles' into (i) transfers of title under the Sale of Goods Act 1979, (ii) conveyances by deed, and (iii) by the delivery of a chattel. With regard to the latter, he observes (at 53): 'Delivery is the usual method for perfecting a gift and almost all the cases on delivery are also cases of gift'.

${ }^{51}$ See eg Pitt v Holt (SC) (n 1) [12], where Lord Walker spoke of a 'voluntary disposition (typically a gift, outright or in settlement)'; Lord Mackay of Clashfern (ed), Halsbury's Laws of England, vol 52: Gifts (5th edn, LexisNexis 2009) para 202; Crossley Vaines (n 48) 305-13. Contrast M Bridge, Personal Property Law (3rd edn, OUP 2002) 102, stating that '[a] declaration of trust and a gift are two very different transactions.' 
Note: This is the manuscript of an article published in (2014) 67 Current Legal Problems 333-372, as submitted to and accepted for publication by the volume editor(s) on 11 June 2014.

It does not contain any later editorial amendments or corrections made during the proofing process. Please use for preliminary reference only and cite the final published version with the appropriate pagination.

few of the most pertinent questions that immediately arise when one attempts to approximate a definition.

For a start, can one say that a gift is simply a gratuitous transfer? The Taxation of Chargeable Gains Act 1992, to use a statutory example, contains a provision under which references to a 'gift' include references to

any transaction otherwise than by way of a bargain made at arm's length so far as money or money's worth passes under the transaction without full consideration in money or money's worth. ${ }^{52}$

And in a recent Court of Appeal case concerning the rectification of a deed by which a mother's interest in real property had been gratuitously conveyed into the joint names of herself and her son, Elias LJ summarized the situation as follows: 'Mrs Day never intended to make a gift to her son, but that is the effect of the conveyance' ${ }^{53}$ Nevertheless, it is clear that not every objectively gratuitous transfer can count as a gift. Such an approach would be over-inclusive. Taken at face value, it would encompass all cases where a performance is mistakenly rendered although it is not owing. Every mistaken payer could otherwise be described as a donor inadvertently making a gift of money to the recipient without intending to do so.

Instead of defining gifts merely by reference to the absence of consideration, it is therefore preferable to identify them by means of a subjective as well an objective element. We could say that objectively there has to be a gratuitous transfer from the donor to the donee, and subjectively an intention with regard to the gratuitous nature of the transfer, or at least a consciousness that it is made without counter-performance and not in discharge of any obligation. This is quite close to what Buckley LJ once described as 'the ordinary primary meaning of "gift", namely 'a voluntary transfer of property made without consideration'.54

However, this definition opens up a variety of new cans of worms. First, what sort of 'transfer' are we talking about? Does there really have to be a 'transfer of property', as Buckley LJ's dictum suggests, or is any transfer of rights sufficient? What about transfers of value in the

\footnotetext{
${ }^{52}$ Taxation of Chargeable Gains Act 1992, s 282(4).

${ }^{53}$ Day v Day [2013] EWCA Civ 280, [2014] Ch 114, [57]. Emphasis added.

${ }^{54}$ Berry $v$ Warnett (Inspector of Taxes) [1981] 1 WLR 1 (CA) 18.
} 
abstract? Can there be a gift of services, for example? Some jurisdictions do not recognize this conceptual possibility. Or how about the voluntary discharge of another's debt? $?^{55}$

Next, does the donee have to be enriched by the donor's gift? If so, must her enrichment be at the donor's expense in the sense that the latter takes it out of his own patrimony and suffers a corresponding disenrichment, or is it enough that it 'comes from' him in some broader sense? Assume that the trustees of a discretionary settlement make an appointment to one of the beneficiaries. Whose gift is that? The preferable view would appear to be that the gift is the settlor's, not the trustees'. If the trustees have blundered when making the appointment, the remedy, if any, lies in the now much-refined Hastings-Bass principle, ${ }^{56}$ not in rescission for mistake. Rescission is the proper remedy only if the settlor was mistaken when establishing the trust.

Turning to the subjective side, is it enough that the donor intends or is conscious of the gratuitous nature of the transfer, or does the donee have to know of the gift, or more narrowly still, positively approve of it? Quite apart from any property transfer aspect (where intentions also play a role), do the parties actually have to reach an agreement of some sort before the special protective regime for gifts will kick in, or do gifts operate purely on a disclaimer basis ${ }^{57}$ A test case here might be that of a person making a payment with full knowledge that the money is not due, for example in order to maintain good relations with a business partner. Is this a gift even if the recipient does not treat it as such? ${ }^{58}$

All in all, there is no doubt a core meaning of the word 'gift' in ordinary language, even in ordinary legal language, but there is also a rather large penumbra of cases where one might struggle for a precise definition. Yet once we say that gifts merit special treatment in their unwinding, that we cannot just apply the ordinary principles of the law of restitution to them, as

${ }^{55}$ Watterson (n 40) 503 regards such cases as examples of 'non-asset-based gifts'.

${ }^{56}$ See notes $22-23$ and text thereto.

${ }^{57}$ For a discussion of the 'one-sided' and the 'two-sided model' of gift transactions see J Hill, 'The Role of the Donee's Consent in the Law in the Law of Gift' (2001) 117 LQR 127.

${ }^{58}$ In Maskell v Horner [1915] 3 KB 106 (CA) 118, Lord Reading CJ had said that '[s]uch a payment is in law like a gift'. The stipulated scenario is not far off the facts of the recent case of Pagel v Farman [2013] EWHC 2210 (Comm), decided after the Supreme Court's ruling in Pitt v Holt (n 1). However, in Pagel v Farman the claimant's 'goodwill gesture' of $£ 5$ million in shares had actually been accepted by the defendant business partner as a 'gift', and so the trial judge simply applied the criteria for the recovery of mistaken gifts as they emerge from Pitt $v$ Holt. 
Note: This is the manuscript of an article published in (2014) 67 Current Legal Problems 333-372, as submitted to and accepted for publication by the volume editor(s) on 11 June 2014.

It does not contain any later editorial amendments or corrections made during the proofing process. Please use for preliminary reference only and cite the final published version with the appropriate pagination.

the presently considered interpretation of Pitt $v$ Holt would have it, then we need to know exactly what gifts (and other protected voluntary dispositions) are.

\section{Applying the Seriousness Test}

The second problem besetting the 'gifts are special' type of approach relates to the inherent uncertainty of the 'serious mistake' test as formulated in Pitt $v$ Holt. ${ }^{59}$ To put it bluntly, the granting of relief is ultimately portrayed as a matter of what legal philosophers might call 'strong' judicial discretion. ${ }^{60}$ According to the Supreme Court, the judge must establish in quite a lot of detail the particular facts and circumstances of the case, then examine them closely, and in the end form a view about the merits of the claim. ${ }^{61}$ This is why their Lordships thought it impossible 'to give more than the most tentative answer' to hypothetical cases, such as the mistaken gift scenarios floated by Professor Burrows in his recent Restatement of the English Law of Unjust Enrichment. ${ }^{62}$ With respect to these, Lord Walker maintained that 'we simply do not know enough about the facts'. ${ }^{63}$

But what does one look for in the facts of a case, and how does one form a view of the claim's merits? In the Court of Appeal, the distinction deriving from Gibbon v Mitchell between the effects of a transaction and its consequences (whatever one may otherwise think of it) ${ }^{64}$ had

\footnotetext{
${ }^{59}$ Also critical of the decision on this account: Davies and Virgo (n 23) 81-82, 84; Ng (n 23) 574-75. Contrast Nolan (n 23) 472-73, who thinks that the uncertainty and its importance 'should not be overstated'.

${ }^{60}$ See eg R Dworkin, 'The Model of Rules' (1967-69) 35 U Chicago L Rev 14, 32-40, reprinted as 'The Model of Rules I' in Taking Rights Seriously (Duckworth 1977) 14, 31-39, commenting critically on HLA Hart, The Concept of Law (Clarendon Press 1961) ch 7, esp 128-44. Note that Hart did not specifically call for the law to adopt an open-textured approach. He in fact favoured 'determinate rules which ... do not require ... a fresh judgment from case to case' (at 133, emphasis in the original). As the postscript to the posthumous second edition reiterates, Hart never envisaged more than the courts exercising a gap-filling 'limited discretionary power to settle cases left incompletely regulated by the law': The Concept of Law (2nd ed, OUP 1994) 273.

${ }^{61}$ Pitt v Holt (SC) (n 1) [126] and [128], partly quoted in the text to $\mathrm{n} 73$.

${ }^{62}$ See A Burrows, A Restatement of the English Law of Unjust Enrichment (OUP 2012) 66.

${ }^{63}$ Pitt v Holt (SC) (n 1) [126].

${ }^{64}$ The distinction was criticized by some judges and commentators as being insufficiently clear and difficult to apply in practice, a view apparently shared by Lord Walker in Pitt v Holt (SC) (n 1) [119]-[123]. In AMP (UK) plc $v$ Barker [2000] EWHC Ch 42, [2001] WTLR 1237, [70], Lawrence Collins J regarded it as 'simply a formula designed to ensure that the policy involved in equitable relief is effectuated to keep it within reasonable bounds and to ensure that it is not used simply when parties are mistaken about the commercial effects of their transactions or have second thoughts about them'. The problem of accommodating the decision in Lady Hood of Avalon $v$
} 
Note: This is the manuscript of an article published in (2014) 67 Current Legal Problems 333-372, as submitted to and accepted for publication by the volume editor(s) on 11 June 2014.

It does not contain any later editorial amendments or corrections made during the proofing process. Please use for preliminary reference only and cite the final published version with the appropriate pagination.

at least helped sort spontaneous mistakes into two relatively straightforward categories, ${ }^{65}$ even though it risked blurring the line between the realms of rescission and rectification. ${ }^{66}$ Similarly, academics who call for gifts to receive special protection against being all too readily unwound have always sought to formulate rules about the sorts of mistakes that should or should not count. Professor Tang's proposal, for example, rests on a two-stage hybrid test which actually bears some resemblance to the approach adopted by the Court of Appeal in Pitt v Holt. At the first stage, he wants to ask whether the donor made the basis of the gift (his purpose in making

Mackinnon (n 31) had led some judges to adopt an artificially wide understanding of the 'effects' category, eg Davis J in Anker-Petersen v Christensen [2001] EWHC B3 (Ch), [2002] WTLR 313, [39]: 'The mistake or misapprehension ... does not necessarily have to be as to the direct terms or direct effect of the document in question; it may also be as to the indirect effect of the document in question'. On the other hand, Lewison $\mathrm{J}$ in Ogden v Trustees of the RHS Griffiths 2003 Settlement (n 12) [25] openly doubted the validity and relevance of the effects/consequences distinction by references to Lady Hood of Avalon, while the Court of Appeal in Pitt $v$ Holt (CA) (n 26) [206] felt constrained by it to introduce an additional category of mistakes which were 'basic' to the transaction: see text to $\mathrm{n} 29$.

${ }^{65}$ See Pitt v Holt (CA) (n 26) [203], where Lloyd LJ said: 'I would accept that, in general, equity does not define dogmatically the categories of case in which it may intervene. Nevertheless, it seems to me that, with the benefit of the review of the relevant cases over the past 150 years or so, it is possible and right to say in what kinds of case the jurisdiction is available, and in which it is not. I do not aim to set out a hard and fast rule as if in legislation, which permits of no exceptions for unforeseen cases, but in my judgment the authorities do justify setting down certain general rules, as to both inclusion and exclusion.'

${ }^{66}$ As another criticism of the effects/consequences distinction, it could be argued that Gibbon v Mitchell (n 20) had illegitimately transposed a criterion which is useful, and indeed logically necessary, in the context of rectifying deeds into a precondition for their rescission. The donor in that case had a life interest under a trust which he purported to surrender in favour of his children in an effort to minimize the inheritance tax payable upon his death. What he failed to appreciate was that his life interest was 'protected', so that the effect of his surrender was to trigger certain discretionary trusts rather than transferring the capital and income absolutely to his children. Millett J recognized that the normal remedy where a deed does not achieve what it was intended to achieve was that of rectification. This remedy allows an instrument to be corrected so as properly to reflect the intention of the party or parties executing. The mistake must therefore necessarily be one relating to the terms or content of the document. In Gibbon v Mitchell, however, rectification was not possible because 'Mr Gibbon's intention could not be carried into effect by this deed or any other deed executed by him' (at 1307). It is against this backdrop that we have to read Millett J's statement about the equitable remedy of rectification being 'only one aspect of a much wider equitable jurisdiction to relieve from the consequences of mistake' (ibid). Since rescission in Gibbon v Mitchell effectively operated as a next-best substitute for rectification, it made sense to insist that the grantor's mistake be 'as to the effects of the transaction itself and not merely as to its consequences or the advantages to be gained by entering into it' (at 1309). Yet this should not obscure the fact that the remedy of rescission does not ordinarily presuppose a mistake about the terms of the disposition which the mistaken party seeks to avoid. Indeed, its most common field of application is precisely that of mistakes made in respect of the reasons for entering into a particular transaction (though in the context of contracts for value only mistakes induced by a misrepresentation will do). There was thus no logical or inherent reason for confining rescission in the gift context to mistakes about the 'effects' of a transaction rather than its 'consequences'. 
this gift, ie the motivating factors behind it) clear to the donee from the outset. If so, then restitution follows upon a failure of that basis. ${ }^{67}$ If not, then Professor Tang moves to a second stage, where he examines whether the donor was labouring under a 'serious' mistake which goes to the very root of the gift. To him, this means that there has to be a 'mistake in the factum of the gift', encompassing primarily mistakes about the 'nature and character of the act' (eg mistakes as to the subject-matter given away) and mistakes about the identity of the beneficiary. ${ }^{68}$

The Supreme Court in Pitt v Holt, by contrast, expressly rejected any attempt to define the category of 'serious mistake' more closely by reference to its nature or content. Lord Walker explained that this was on account of the 'general disinclination of equity to insist on rigid classifications expressed in abstract terms. ${ }^{99}$ In particular, he pointed out that equity had never adopted the classificatory scheme of mistake which Roman law used and indicated that the Supreme Court was not minded to do so on this occasion. ${ }^{70}$ Accordingly, the only guidance the decision provides is a much watered-down version of the criteria identified as relevant by the Court of Appeal, Lord Walker saying that the seriousness test 'will normally be satisfied only when there is a mistake either as to the legal character or nature of a transaction, or as to some matter of fact or law which is basic to the transaction. ${ }^{71}$ Applying this standard, we must conclude either that Pitt $v$ Holt was a case out-of-the-ordinary, or that the mistake about the tax consequences of the settlement was seen by the Supreme Court as somehow 'basic' to the transaction (contrary to the view of the judges in the Court of Appeal), because the mistake clearly did not relate to its legal character or nature.

${ }^{67}$ Tang (n 43) 29-30. The Court of Appeal's approach differs in that it would tend to allow the spontaneous mistake about an existing fact which is somehow 'basic' to the transaction to justify rescission even if the donor did not disclose the basis of the gift to the donee: see text to $n 29$.

${ }^{68}$ Tang (n 43) 30-33. He nevertheless concedes that '[i]t would be rash to assert the categories of serious mistakes are closed and fixed. The courts should be able to develop new categories of mistakes' (at 32).

${ }^{69}$ Pitt v Holt (SC) (n 1) [123].

70 ibid. He added that the Gibbon $v$ Mitchell test, 'at any rate if applied narrowly', would only cover the Roman category of error in negotio (mistake as to the nature of an intended transaction), but not error in persona (mistake as to the identity of the other party to the transaction), error in corpore (mistake as to the subject-matter or the transaction) or error in substantia (mistake as to a quality of the subject-matter). It is submitted that this rests on far too restrictive an understanding of the Gibbon v Mitchell test. A mistake as to the 'effects' of a transaction can quite easily and naturally encompass the first three categories at least.

${ }^{71}$ Pitt v Holt (SC) (n 1) [122] (emphasis added). 
It may be added that the discretion envisaged by the Supreme Court is even stronger than first meets the eye if one bears in mind that a judge is not merely to consider the circumstances of the mistake at the moment of transfer, but also its consequences further down the line, primarily for the donor, yet potentially also for the donee as well as third parties. ${ }^{72}$ The full extent of judicial power under such a discretionary approach is best summed up in the following passage from Lord Walker's judgment:

The court cannot decide the issue of what is unconscionable by an elaborate set of rules. It must consider in the round the existence of a distinct mistake..., its degree of centrality to the transaction in question and the seriousness of its consequences, and make an evaluative judgment whether it would be unconscionable, or unjust, to leave the mistake uncorrected. The court may and must form a judgment about the justice of the case. $^{73}$

Why might such an approach be regarded as problematic to apply to mistaken gifts generally, even assuming that we can define what a 'gift' is?

First and foremost, if restitutionary relief is to depend on a judge exercising his or her discretion in 'setting aside' the gift first, that would seem to suggest that all mistaken gift cases must now go to court. But that is not how the law has hitherto been understood. While we are familiar with the idea of going to court to have a formal instrument such as a deed rescinded (as in Pitt v Holt, Gibbon v Mitchell, Ogilvie v Littleboy, and Lady Hood of Avalon v Mackinnon), there is already a question mark over whether rescission necessitates judicial involvement where there has been a transfer of some chattel by simply delivery, as in the necklace example posited at the beginning. Some people would argue that rescission in such a case was a self-help remedy in equity as much as at common law. ${ }^{74}$

${ }^{72}$ See esp ibid [126], where Lord Walker speaks of 'the circumstances of the mistake and its consequences for the person who made the vitiated disposition' besides 'other findings of fact ... in relation to change of position or other matters relevant to the exercise of the court's discretion.'

${ }^{73}$ Pitt v Holt (SC) (n 1) [128].

${ }^{74}$ On a widespread view, rescission is always the act of the party concerned, and ' $[\mathrm{t}]$ he function of a court in which proceedings for rescission are taken is to adjudicate upon the validity of a purported disaffirmance as an act avoiding the transaction ab initio, and, if it is valid, to give effect to it and make appropriate consequential orders': Alati v Kruger [1955] HCA 64, 94 CLR 216, 224. Against this understanding of rescission, at least on the equity side: J O’Sullivan, 'Rescission as a Self-Help Remedy: A Critical Analysis' (2000) 59 CLJ 509. See also the discussion in D O’Sullivan, S Elliott, and R Zakrzewski, The Law of Rescission (OUP 2008) paras 11.55-11.105. 
Less controversially perhaps, consider Lord Scott's hypothetical in Deutsche Morgan Grenfell $v$ IRC of the man who makes a gift of $£ 1,000$ to another mistakenly believing the recipient to be impecunious. ${ }^{75}$ If the donor sought to recover this amount, would he have to go to court for a formal rescission order even if the donee did not resist his claim, or would it at any rate be prudent to do so?

This is by no means a purely theoretical question. To know whether or not a donor has a legal right to recover can be crucial. Just assume for the moment that the amount involved was $£ 100,000$ instead of merely $£ 1,000$ and that the donee was perfectly willing to return the money. This variation of Lord Scott's hypothetical has huge tax implications. Although there has been no gift tax as such in the UK since the mid-1980s, ${ }^{76}$ inheritance tax will fall due on the gift if the donor dies within seven years of making it. The gift is therefore described as a "potentially exempt transfer' for inheritance tax purposes. ${ }^{77}$ It becomes a chargeable transfer if the donor fails to survive for seven years, otherwise it becomes fully exempt after the expiry of this period. According to section 150 of the Inheritance Tax Act 1984 (a provision which also played a role in Pitt v Holt $),{ }^{78}$ where a chargeable transfer is voidable and set aside, it is treated as if it had been void ab initio so that any tax payable on it ceases to be so payable and any tax already paid can be recovered. Therefore, if the generous donor who was mistaken about the donee's financial position has a right to restitution, his original gift and its repayment have no tax implications. By contrast, if the donee repays the money because he feels morally constrained to act in this way (ie because his personal conscience dictates that he should not keep the money), even though he has no legal obligation to do so (ie it would not, in Lord Walker's terminology, be objectively unconscionable for him to keep it), then the repayment itself may actually be seen as a new gift in its own right.

Thought through to its logical conclusion, the application of the Supreme Court's combined 'seriousness' and 'unconscionability' test can ultimately make all the difference between having either a completely tax-neutral transfer and retransfer of money, or having not

\footnotetext{
${ }^{75}$ See notes $14-15$ and text thereto.

${ }^{76}$ In 1986, the former capital transfer tax regime (in force since 1975) was replaced by inheritance taxation.

${ }^{77}$ Inheritance Tax Act 1984, s 3A.

${ }^{78}$ See Pitt $v$ Holt (SC) (n 1) [130].
} 
merely one, but two 'potentially exempt' and thus potentially chargeable transfers. ${ }^{79}$ If worst comes to worst, we may therefore in future commonly encounter a scenario where the parties do not in fact squabble about repayment or avoidance (as indeed they did not in Pitt v Holt), but where they find themselves having to persuade the Revenue or some tax tribunal that the donor's mistake was one which a Chancery judge, guided by the Supreme Court in Pitt v Holt, would regard as 'sufficiently serious'. ${ }^{80}$ With all due respect to their Lordships, such an exercise is terribly hard to envisage.

The great uncertainty imported by the strong discretionary element in the Supreme Court's seriousness test is perhaps the main argument against overenthusiastically embracing the idea that there is now a distinct law of gifts with special rule about recovery which lie half-way between the contractual rules we know so well and the pure causative mistake test that has established itself in the law of restitution since Barclays Bank $v$ Simms ${ }^{81}$ Yet if this were indeed how future judges understand and develop Pitt $v$ Holt ${ }^{82}$ then it is very likely that mistakes will in due course have to be sorted into different categories. One can safely predict that the most contentious category will be the one that Civilian lawyers call the category of 'motivational mistakes', or more precisely, spontaneous motivational mistakes, namely mistakes in respect of the donor's reasons for making the transfer that are not induced by a misrepresentation on the donee's part. Maybe we would end up with a list of reasonable motives to have, where

\footnotetext{
${ }^{79}$ This problem did not exist until 1986, when ss 148 and 149 of the Capital Transfer Tax Act 1984 (which was renamed Inheritance Tax Act at the same time) were repealed. They applied to 'mutual gifts' and provided that where, after receiving a gift, the donee makes a reciprocal gift of equivalent value to the donor, the two transfers cancel each other out. In consequence, the donee's gift was exempt from capital transfer tax (s 148), and he donor could reclaim any tax already paid on the original transfer (s 149).

${ }^{80}$ Unless we require a judicial act of rescission in every case (rather than just for deeds), many informal gift cases will not reach the High Court, where the Revenue can be joined to the proceedings as in Pitt $v$ Holt. Instead, the issues of whether the donor had a right to restitution or whether a retransfer by the donee is itself a fresh gift back will have to be determined as incidental matters when inheritance tax is assessed. Disputes arising in connection with these questions then follow the ordinary appeals procedure against direct tax decisions.

${ }^{81}$ In Pitt v Holt (SC) (n 1) [127], Lord Walker emphatically rejected the reproach, made in the context of identifying what a mistake is, that certain distinctions drawn by the Court of Appeal were susceptible to 'judicial manipulation'. Yet there is a danger that judges exercising their judicial super-discretion along the relatively unstructured lines of inquiry suggested by Pitt $v$ Holt will expose themselves all the more to such or similar allegations.
}

${ }^{82}$ As eg in Pagel v Farman (n 58). 
Note: This is the manuscript of an article published in (2014) 67 Current Legal Problems 333-372, as submitted to and accepted for publication by the volume editor(s) on 11 June 2014.

It does not contain any later editorial amendments or corrections made during the proofing process. Please use for preliminary reference only and cite the final published version with the appropriate pagination.

motivational mistakes count, and a blacklist of unreasonable ones, where they do not. ${ }^{83}$ In any event, the process of working all this out through individual cases would inevitably take time.

\section{Different Rules for Different Types of Remedies?}

There is an alternative interpretation of Pitt $v$ Holt. It has been most prominently put forward by the current Chancellor of the High Court, Sir Terence Etherton. He argues that the decision is not concerned with establishing a special law of gifts, but that it is simply a ruling on the equitable remedy of rescission and its proprietary implications. ${ }^{84}$ On this approach, the real distinction would appear to be between what restitution lawyers call 'proprietary restitution' by means of court-ordered equitable rescission on the one hand, and common law remedies like the action for money had and received on the other. Because the latter only ever entail personal claims, there are no good grounds for disapplying the simple causative mistake test deriving from Barcalys Bank $v$ Simms in the gift context. ${ }^{85}$

This chimes with something that Lord Justice Lloyd said in the Court of Appeal. He was careful to emphasize that his judgment was only dealing with the equitable side of things, and for understandable reasons he refrained from entering into speculations as to whether the relevant principles at common law and in equity are, or ought to be, the same. ${ }^{86}$

Viewed in this light, one could regard the criteria of 'seriousness' and 'unconscionability' as linking up with an ongoing debate amongst restitution lawyers, namely about the circumstances under which 'unjust enrichment' as an event triggers a proprietary response, and about the nature of that response. We might thus try to tie Pitt $v$ Holt in with cases like Chase Manhattan Bank NA v Israel-British Bank (London) Ltd, ${ }^{87}$ a mistaken double

\footnotetext{
${ }^{83}$ An example of such an 'unreasonable motive' may be the one given by Burrows, Restatement (n 62) 66 ('example 7') of a person making a donation to the Red Cross in the mistaken belief that the mayor and vicar have also made donations.

${ }^{84}$ T Etherton, 'The Role of Equity in Mistaken Transactions' (2013) 27 TLI 159.

85 ibid 167-68.

${ }^{86}$ Pitt v Holt (CA) (n 26) [166]. Lloyd LJ thought that the claim in Pitt v Holt had to be based on equity 'in order to claim proprietary relief by setting aside the transaction'.

${ }^{87}$ Chase Manhattan Bank NA v Israel-British Bank (London) Ltd [1981] Ch 105 (Ch D).
} 
payment scenario, and with what Lord Browne-Wilkinson said about this decision in Westdeutsche Landesbank Girozentrale v Islington London Borough Council. ${ }^{88}$ Meanwhile, however, Sir Terence Etherton himself actually wants to draw a line between the 'Pitt $v$ Holt equitable right to rescission' and forms of 'proprietary relief for a common law claim in unjust enrichment as a result of the claimant's spontaneous mistake', including the Chase Manhattan type of 'right to trace in equity pursuant to a [constructive] trust' ${ }^{89}$

This is not the right place to enter into the whole controversy about 'proprietary restitution', although a little more will have to be said about it later. ${ }^{90}$ For the time being, we should merely note an important point underlying Sir Terence's observation about the division between common law and equity. The point is that different remedies have traditionally been used to deal with what we now describe as 'mistaken gift' cases. If a deed was involved, the proper means of redress was going to court and having it set aside, or where appropriate, rectified. For simple gifts of money, the common law action for money had and received was arguably on the cards, albeit that for a long time claimants faced the hurdle of overcoming the 'mistake of law bar' and the 'supposed liability' test. ${ }^{91}$ If, on the other hand, the gift was made by the delivery of a chattel (as in our necklace example), then it was necessarily back to rescission, with or without the involvement of a court of equity. This was because the range of common law personal pecuniary remedies could not easily be stretched to cover gifts of chattels. An action for quantum valebat was probably the closest one got, but no case ever suggested that a mistaken donor might use it to recover the value of goods delivered to the donee. ${ }^{92}$

${ }^{88}$ Westdeutsche Landesbank Girozentrale v Islington London Borough Council [1996] UKHL 12, [1996] AC $669,702-9,714-15$.

${ }^{89}$ Etherton (n 84) 168-69.

${ }^{90}$ See text following n 164

${ }^{91}$ See above, n 5 and text to n 7. Cf also C Mitchell, P Mitchell and S Watterson (eds), Goff \& Jones: The Law of Unjust Enrichment (8th edn, Sweet \& Maxwell 2011) para 9-110: 'Historically, the prevailing view that only liability mistakes of fact were restitution-grounding effectively ruled out in limine a personal claim to restitution for a mistaken gift, leaving donors to look to equity's jurisdiction.'

92 The issue is seen by A Tettenborn, Law of Restitution in England and Ireland (3rd edn, Cavendish 2002) para 3-22, who explains that the remedy was 'traditionally limited to goods accepted in circumstances suggesting an intention to charge'. 
Nothing much appears to have changed. At least outside the money context, 'rescission' is still widely treated as the appropriate (and only) remedy for aggrieved donors. ${ }^{93}$ In this area, the forms of action really do seem to rule us from their graves. What is sorely needed is a rationalization of the remedies available at common law and in equity, and to some extent an integration of their respective elements. We should not have different rules applying to different ways of making a gift, or for different modes of recovery, except to the extent that these differences can be substantively justified.

\section{A Comparative Side-Glance}

Before attempting to sketch how English law might best be taken forward after Pitt $v$ Holt, it is worth throwing a brief side-glance at how the problem of mistaken gifts is handled elsewhere. This is not because other legal systems can or should tell us what to do, but because we can often learn something about our own system by understanding how and why other systems do things differently. Their experiences allow us to put some of the issues and suggestions discussed here into sharper relief.

There are two main lessons to be learnt from a comparative excursion. The first is that it can be extremely hard and wearisome to come up with a proper theory of gifts. German lawyers have had to face up to the challenge because the German law of unjustified enrichment requires every performance by one party to another to be referable to some 'legal basis' or 'causa'. 94 Scholars there spent a good part of the 19th century fussing over the most appropriate way to conceptualize a gift. ${ }^{95}$ The issues they disagreed on were by and large similar to those outlined

93 'Rescission' of the gift is then understood not as a pre-condition for getting any restitutionary claim off the ground (as on the approach discussed in the text to notes 41-46, which treats gifts as special non-bargain transactions deserving of the law's protection), but rather as one particular remedy that competes with other potential methods of unwinding mistaken transfers (ie in allowing specific as opposed to value-based restitution).

94 An overview of the German law of unjustified enrichment may be found in B Häcker, Consequences of Impaired Consent Transfers (Mohr Siebeck 2009, republished by Hart Publishing 2013) 25-28.

${ }^{95}$ For details of the debate and its protagonists see the account with further references given by TJ Chiusi in $J$ von Staudingers Kommentar zum Bürgerlichen Gesetzbuch, Buch 2: Recht der Schuldverhältnisse, \$\$ $516-534$ (Sellier de Gruyter 2013) Vorbemerkungen zu §§ 516 ff, paras 29 to 34; G Pfeifer in M Schmoeckel, J Rückert and R Zimmermann (eds), Historisch-kritischer Kommentar zum BGB, Band III, Schuldrecht: Besonderer Teil, $\$ \$ 433-$ 853, 1. Teilband (Mohr Siebeck 2013) §§ 516-534, paras 9 to11. 
Note: This is the manuscript of an article published in (2014) 67 Current Legal Problems 333-372, as submitted to and accepted for publication by the volume editor(s) on 11 June 2014.

It does not contain any later editorial amendments or corrections made during the proofing process. Please use for preliminary reference only and cite the final published version with the appropriate pagination.

above with respect to English law, especially the question of (express or implied) acceptance by the donee. In the end, the view that won the day was the one that regarded every gift as a type of gratuitous contract, ${ }^{96}$ something which is of course possible in a Civilian system without a distinct doctrine of consideration.

Accordingly, the German Civil Code deals with gifts alongside various other specific contracts as part of the law of obligations. ${ }^{97}$ To avoid misunderstandings, it should be noted that the contractual categorization of gifts does not mean that German law treats informal promises of a gratuitous benefit as enforceable once they are accepted by the other party. Instead, only gratuitous promises made in solemn notarial form are binding on the promisor (functionally comparable to a deed in English law), with the lack of such form being 'healed' by actual performance. ${ }^{98}$ Alternatively, where the gift is executed without a preceding promise, the requisite contract is taken to be (expressly or impliedly) concluded at the moment when property is transferred from the donor to the donee. ${ }^{99}$ If English law wanted to develop and refine its theory of gifts (or if it was felt that it had to following Pitt $v$ Holt), an awareness of the German deliberations would yield much food for thought, without necessarily calling into question the doctrine of consideration.

The second lesson to learn from comparative law is that there is nothing approximating a consensus about the merits of allowing gifts tainted by motivational mistake to be recovered by the donor. Some legal systems allow recovery, others do not. ${ }^{100}$ Austria may be picked out as a

\footnotetext{
${ }^{96}$ Motive zu dem Entwurfe eines Bürgerlichen Gesetzbuches für das Deutsche Reich, Band 2 (Guttentag 1888) 286-89. Cf also Protokolle der Kommission für die zweite Lesung des Entwurfs des Bürgerlichen Gesetzbuchs, Band 2 (Guttentag 1898) 1-8. The compilers of the Civil Code were persuaded that the construction was desirable in order to enable the donee to reject an unwanted gift.

${ }^{97}$ The law of inter vivos gifts is contained in $\S \S 516-534$ of the German Civil Code (Bürgerliches Gesetzbuch, abbreviated BGB). Defining the notion of a 'gift', § 516(1) BGB provides: 'The conferral of a benefit, by means of which one party enriches another out of his own assets, is a gift if both parties are agreed that the conferral of the benefit shall be gratuitous.'

$98 \S 518$ BGB. The latter proviso was introduced to prevent the donor from recovering a gift made in the mistaken belief that a gratuitous informal promise was binding: Protokolle, Band 2 (n 96) 9-12, esp 11.

99 The gift contract must not be confused with the agreement between the transferor-donor and the transfereedonee about the transfer of property in the subject-matter of the gift. The latter is classified as a 'real agreement', which the BGB also regards as contractual. Every conveyance under German law involves such a 'real agreement'.

${ }^{100}$ Lack of space forbids the discussion of US case law on the question, but it is worth mentioning that the recovery of gratuitous transfers for tax mistakes in particular has attracted a good deal of judicial and academic attention there. See only Stone v Stone 319 Mich 194, 29 NW 2nd 271 (1947), noted in (1948) 61 Harvard L Rev
} 
Note: This is the manuscript of an article published in (2014) 67 Current Legal Problems 333-372, as submitted to and accepted for publication by the volume editor(s) on 11 June 2014.

It does not contain any later editorial amendments or corrections made during the proofing process. Please use for preliminary reference only and cite the final published version with the appropriate pagination.

convenient example in the first category. Its Civil Code contains a provision stating that errors relating to motive in gratuitous inter vivos transactions are to be subject to the same rules as errors relating to motive in testamentary dispositions. ${ }^{101}$ As regards the latter, motivational mistakes are expressly recognized as grounds for rescission, albeit that there is some debate about the exact conditions. ${ }^{102}$ For inter vivos gifts, most commentators nowadays treat any causative mistake as generating a right to rescind, ${ }^{103}$ while the courts tend to maintain a more restrictive approach, sometimes requiring the donor to have disclosed his motive to the donee and usually insisting that it must have been his sole or main reason for entering into the transaction. ${ }^{104}$

Germany falls into the other category of legal systems. It does not allow inter vivos gifts to be recovered for mere motivational mistakes. This is a direct result of conceptualizing every such gift as a type contract. As might be expected, the rules on rescission of contracts closely circumscribe what kinds of mistakes count. Apart from rescission for fraud and duress, ${ }^{105}$ the German Civil Code enables contracting parties to avoid agreements they have entered into only if they were mistaken as to the nature or content of the agreement (including mistakes about the

553; Lowry v Kavanagh 322 Mich 532, 34 NW 2nd 60 (1948), noted by DA Kraemer in (1949) 32 Marquette L Rev 285 and by NS Peterman in (1949) 47 Michigan L Rev 859; Walton v Bank of California 218 Cal App 2d 527, 32 Cal Rptr 856 (1963), esp 542-547; American Law Institute, Restatement Third: Restitution and Unjust Enrichment (American Law Institute Publishers 2011) vol 1, 150.

$101 \S 901$ ABGB, 3rd sentence, referring to $\S 572$ ABGB.

102 While the wording of $\S 572$ ABGB suggests that the testator's mistake is only relevant if the motive is disclosed in the will and if it is the sole reason for making the disposition, a widespread view holds that any causative mistake suffices: see the overview with further references given by $\mathrm{R}$ Welser in P Rummel (ed), Kommentar zum Allgemeinen bürgerlichen Gesetzbuch, Band 1: \$§ 1-1174 (3rd edn, Manz 2000) § 572 para 3; P Apathy in H Koziol, P Bydlinski and R Bollenberger (eds), Kurzkommentar zum ABGB (3rd edn, Springer 2010) $\S 572$ para 4.

${ }^{103}$ For an overview with further references see R Bollengerber in Kurzkommentar zum ABGB (n 102) $\S 901$ paras 4-5; A Fenyves in A Fenyves, F Kerschner and A Vonkilch (eds), Großkommentar zum ABGB: KlangKommentar, §\$897-916 (3rd edn, Verlag Österreich 2011) §901 paras 17-18; P Rummel in Rummel (ed), Kommentar zum Allgemeinen bürgerlichen Gesetzbuch (n 102) §901 para 9; P Apathy and A Riedler in M Schwimann (ed), ABGB Praxiskommentar, Band 4: §§ 859-1089 (3rd edn, LexisNexis 2005) § 901 paras 3-5.

${ }^{104}$ See eg OGH (2.3.1955) 1 Ob 81/55, SZ (Entscheidungen des Österreichischen Obersten Gerichtshofes in Zivilsachen) 28/60, OGH (10.1.1989) 4 Ob 606/88, JB1 (Juristische Blätter) 1989, 446.

${ }^{105} \S 123$ BGB. 
identity of the other contracting party $)^{106}$ or if their mistake related to an 'essential characteristic' of its subject-matter or of the other party. ${ }^{107}$ So while German law does not rule out altogether the possibility of a contract being rescinded for spontaneous mistake, it excludes ordinary motivational mistakes, ${ }^{108}$ and where rescission is permitted, it makes the rescinding party compensate the other for any reliance losses. ${ }^{109}$

Today, most German lawyers treat it as axiomatic that gifts are subject to the same restrictions on rescission as contracts for value. They regard the suggestion that a gift should be recoverable ${ }^{110}$ for a 'pure' motivational mistake as heretical. Yet this was not nearly as evident at the time when the Civil Code was first enacted as it appears nowadays. ${ }^{111}$ During the late 19th century already, the compilers of the Code had discussed whether or not it was appropriate to apply the same rules of mistake across the board, and they considered adopting a more lenient regime for parties who gratuitously bestow a benefit on another. ${ }^{112}$ Given that German law is

106 § 119(1) BGB reads: 'A person who, when making a declaration of intention, was mistake about its content, or did not intend to make a declaration with such content at all, can avoid the declaration if it is to be assumed that he would not have made it in knowledge of all the relevant facts and on a rational appreciation of the case.'

$107 \S 119(2)$ BGB reads: 'A mistake about such characteristics of a person or a thing which are generally regarded as essential is also deemed to be a mistake about the content of a declaration.' The generally accepted test of 'essentiality' is that the mistake has to relate to an attribute which would be thought relevant by the reasonable person. While attributes upon which the value of an object depends are typically regarded as relevant, the value of the object in and of itself is not considered to be an essential attribute.

108 There is actually a lively debate, which will not be pursued further here, over whether mistakes about 'essential characteristics' under $\S 119$ (2) BGB are properly characterized as special cases of motivational mistake, ie cases where the law exceptionally allows rescission, or whether they are of a quality more akin to the mistakes mentioned in $\S 119(1)$ BGB.

$109 \S 122$ BGB.

${ }^{110}$ Where a gift contract is rescinded, recovery is practically always through a personal claim in unjustified enrichment ( $\$ \S 812 \mathrm{ff}$ BGB). Due to German law's adherence to the so-called 'principle of abstraction', rescission of the gift contract leaves the transfer of property wholly unaffected.

111 The best account in English tracing this in greater detail is provided by $\mathrm{T}$ Krebs, Restitution at the Crossroads: A Comparative Study (Cavendish Publishing 2001) 60-64.

112 Motive zu dem Entwurfe eines Bürgerlichen Gesetzbuches für das Deutsche Reich, Band 1 (Guttentag 1888) 201. At this stage in the drafting process, the 'will theory' of contracting still prevailed, so that a party's declaration of intention was regarded as void (rather than merely voidable) if based on a relevant mistake. The particular issue discussed by the compilers was whether and when it was appropriate to treat a declaration of intention as fully valid and binding despite the existence of an otherwise relevant mistake on the ground that the party making it had been grossly negligent when doing so. They did not expressly envisage extending the categories of relevant mistake in the gift context. 
very generous about setting aside testamentary gifts, ${ }^{113}$ and given that the Civil Code contains a number of provisions indicating that a donee's receipt is by and large less secure than that of a party who has provided value in exchange, ${ }^{114}$ there would have been nothing exceptional about such a policy choice. Only the practical difficulties of implementing a special set of rules governing mistake in non-bargain transactions ultimately swayed the compilers' minds against the proposal. ${ }^{115}$ However, that did not put an end to the debate. A number of authors writing at the beginning of the 20th century expressed concerns about the newly drafted provisions on rescission for mistake. They were particularly uneasy about applying the 'essential characteristic' test to gifts. ${ }^{116}$ What, after all, is 'generally regarded' by a 'reasonable person' as being 'essential' to another person or a thing ${ }^{117}$ in the highly idiosyncratic realm of gift-giving? This led to the suggestion that gifts warrant an especially broad reading of the relevant statutory rules. ${ }^{118}$ A different and somewhat bolder approach is to argue for an analogy with testamentary

${ }^{113} \S 2078$ BGB allows the rescission of testamentary dispositions not only for any causative mistake, including all types of motivational mistake, but also where the testator's expectations have been disappointed, ie for a mere misprediction. It excludes the application of $\S 122$ BGB (on which see text to $\mathrm{n} 109$ ), so that no reliance damages are payable.

${ }^{114}$ See only $§ 528$ BGB (claim to recover a gift where the donor is subsequently impoverished), $§ 530$ BGB (right to revoke a gift for the donee's gross ingratitude), $§ 816(1)(2)$ BGB (unjust enrichment claim against a bona fide purchaser of an asset who has not provided value in exchange), and $\S 822$ BGB ('leapfrogging' claim in unjust enrichment against a person to whom the primary enrichee has gratuitously passed on the enrichment).

${ }^{115}$ Motive, Band 1 (n 112) 201: 'It is true that there is something to be said for a more lenient treatment of the person making a declaration [of intention] in cases of legal transactions by means of which something is promised or transferred to another without consideration. Yet the distinction between transactions for value and gratuitous transactions is hard to operate in practice, however simple it may appear to be. Establishing whether or to what extent a transaction is gratuitous often gives rise to considerable difficulties, in particular where so-called 'mixed' transactions are concerned. The distinction would introduce into the application of the provisions an uncertainty which would inevitably have to reduce their practical value.' (Translation by the author).

116 O Lenel, 'Der Irrtum über wesentliche Eigenschaften' (1902) 44 JhJB (Jherings Jahrbücher für die Dogmatik des bürgerlichen Rechts) 1, 24-26; S Schloßmann, Der Irrtum über wesentliche Eigenschaften der Person und der Sache nach dem Bürgerlichen Gesetzbuch (Fischer, Jena 1903) 67-71; L Lippmann, 'Studien zu $\S 119$ Abs. 2 BGB' (1907) 102 AcP (Archiv für die civilistische Praxis) 283, 377-87. For the English-speaking reader, these contributions are conveniently summarized by Krebs (n 111) 61-63.

${ }^{117}$ Cf the translation of $\S 119(2)$ BGB and comments in $\mathrm{n} 107$.

118 See esp Lenel (n 116) 25-26; Schloßmann (n 116) 68-71. 
gifts. ${ }^{119}$ It would allow inter vivos gifts to be recovered for any causative mistake, including all motivational mistakes, subject only to the donor making good the donee's reliance losses. ${ }^{120}$ The 17th century French jurist Jean Domat has been invoked in support of such a radical departure from what is now the established wisdom in German law, ${ }^{121}$ especially his observation that 'motive takes the place of the cause' in the case of gifts. ${ }^{122}$ What all this goes to show is that even legal systems with supposedly well-settled rules governing the restitution of mistaken gifts cannot necessarily serve as a role model for English law one way or the other, because they may have arrived at their position by long and winding roads, and indeed almost as if by accident of legal history.

Our short comparative excursion may be concluded with an interesting (albeit admittedly rather special) example of a German court circumventing the actual or supposed restrictions on the setting aside of inter vivos gifts. Two years ago, the Federal Supreme Court ${ }^{123}$ was asked to rule on a case where in the course of an amicable separation, a husband had made a substantial gift of money to his estranged wife to enable her to buy a place where she and the couple's son could live. He also paid for a second flat which was bought in her name as an investment. Unbeknown to the husband, the son was not his biological child. Since it was not alleged that the wife had ever actively misled him about the child's paternity, the scenario looks like a prime instance of gifts induced (at most) by an irrelevant spontaneous motivational mistake on the

${ }^{119}$ Such an analogy with $\S 2087$ BGB, a provision outlined in $\mathrm{n} 113$ above, is proposed by Lippmann (n 116) 379, 387-404, and also by W Flume, Allgemeiner Teil des Bürgerlichen Rechts: Zweiter Band: Das Rechtsgeschäft (4th edn, Springer 1992) 426.

120 The latter qualification is made by Flume (n 119) with reference to $\S 122$ BGB (on which see text to n 109), but is rejected by Lippmann (n 116) 380, 386-87, 396, on the ground that $\S 2078(3)$ BGB expressly excludes the application of $\S 122$ BGB.

${ }^{121}$ Flume (n 119) 171-73.

${ }^{122}$ More specifically, Domat had spoken of a 'just and reasonable motive': J Domat, Les Loix Civiles dans leur Ordre Naturel (2nd edn, Paris 1697) vol 1, 65: 'Dans les donations, \& dans les autres contrats où l'un seul fait, ou donne: \& où l'autre ne fait, \& ne donne rien; l'acceptation forme la convention. Et l'engagement de celuy qui donne, a son fondement sur quelque motif raisonnable \& juste, comme un service rendu, ou quelque autre merite [sic] du donataire, ou le seul plaisir de faire du bien. Et ce motif tient lieu de cause de la part de celuy qui reçoit \& ne donne rien.' (Book 1, title 1, section 1, para 6, emphasis added).

${ }^{123}$ The Federal Supreme Court (Bundesgerichtshof, abbreviated BGH) is the highest German court in civil and criminal matters. 
husband's part. ${ }^{124}$ The Federal Supreme Court nevertheless allowed recovery. ${ }^{125}$ As regards the property where the wife and son lived, it held that the gift was fundamentally premised on an assumption about the child's paternity which had been proved false and which thus led to the basis of the transaction failing or being 'frustrated'. ${ }^{126}$ Although the same could not be said with respect to the flat bought as an investment, the Federal Supreme Court maintained that the wife had in any event breached a duty of disclosure. She should have told her husband of the possibility that the son was another man's. Not telling him was tantamount to making a fraudulent misrepresentation. This way of looking at the issue enabled the husband to rescind the gifts and claim repayment of the money. ${ }^{127}$

\section{Refining the 'Causative Mistake Test'}

In the light of the above analysis, this final part of the paper will seek to show that it is perfectly possible for English law to integrate the law relating to mistaken gifts into its ordinary law of unjust enrichment, using a simple causative mistake test, while at the same time accommodating most of the substantive concerns underlying the Supreme Court's decision in Pitt $v$ Holt or otherwise driving calls for an additional 'seriousness' hurdle. The beauty of this approach is not only that it avoids the problems of establishing a special regime for gifts, but that it actually enables Pitt $v$ Holt to function as a catalyst for developing and rationalizing the principles governing restitution for unjust enrichment as a whole.

There are various aspects or steps to this process of refinement, spanning the full range of the unjust enrichment inquiry (from the identification of a mistake to the adequate protection of the donee and affected third parties). Although the remarks which follow are premised on the orthodox understanding of English law operating an 'unjust factors' orientated model of

124 This had been the verdict of the appellate court below: OLG München (28.1.2009) 20 U 2673/08, FamRZ (Zeitschrift für das gesamte Familienrecht) 2009, 1831.

${ }^{125}$ BGH (27.6.2012) XII ZR 47/09, NJW (Neue Juristische Wochenschrift) 2012, 2728.

126 The relevant provision of the German Civil Code is $\S 313$ BGB (Störung der Geschäftsgrundlage), which covers both the initial failure of basis and the subsequent frustration of a transaction.

127 The case was referred back for further findings of fact and was ultimately treated and decided as a damages claim for the wife's fault in bringing about the gift (culpa in contrahendo): OLG München (14.11.2012) $20 \mathrm{U}$ 2673/08, NJW (Neue Juristische Wochenschrift) 2013, 946. 
restitution for unjust enrichment, it should be emphasized that they are equally amenable to an analysis is terms of 'absence of basis'. ${ }^{128}$

Here is an outline the basic scheme up-front, best read perhaps with mental reference to the necklace example given at the beginning. ${ }^{129}$ Assuming that the donor's mistake is not fundamental enough to prevent title passing altogether, ${ }^{130}$ the starting point is that the donee has been enriched at the donor's expense. That enrichment is unjust if the donor was labouring under a causative mistake when making the gift. His right to recover the enrichment is not dependent on any 'bad behaviour' on the part of the donee, but is subject to relevant changes of position. In the first instance, the donor has a personal claim to recover the value of the gift. It is only if the donor wants to recover his gift in specie (ie if he seeks 'proprietary restitution') that we have to ask in a second step whether and how the transfer of property that has taken place can be 'set aside'.

What, then, are the concerns emerging from Pitt $v$ Holt that the law of restitution for unjust enrichment must or should take on board, and how can it cater for them within the ordinary framework of inquiry, as it ought to apply to any mistaken transfer outside the contractual sphere?

\section{Establishing a Genuine Mistake}

The first concern is that the claimant should have made a genuine mistake. There are different facets to this criterion. One goes to the very notion of 'mistake', and here Pitt $v$ Holt takes a significant step which the law of restitution for unjust enrichment has to digest and internalize whatever interpretation of the judgment one adopts. Apart from reminding us that mistakes relate to the past or present and need to be distinguished from 'mispredictions' about future

128 It is true that, in an 'absence of basis' world, gifts would need to conceptualized as 'legal grounds' justifying the defendant-donee's enrichment at the claimant-donor's expense. However, given that any (genuine) causative mistake would normally suffice to avoid the legal basis for a transfer, there would be much less pressure on the notion of a 'gift' and consequently little practical need to develop a fully-blown theory of gifts as a category.

129 That is the situation of an informal gift effected by simple delivery. Formal gifts made by deed are discussed in the text following $\mathrm{n} 175$.

${ }^{130}$ It is generally thought, following Cundy v Lindsay (1878) 3 App Cas 459 (HL), that mistakes as to the identity of the other party (and following $R v$ Middleton (1873) LR 2 CCR 38, possibly also identity mistakes about the object to be conveyed) are of this level of fundamentality, although it may well be that the transferor's identity mistake actually needs to be known to the recipient in order to prevent the passing of title. 
Note: This is the manuscript of an article published in (2014) 67 Current Legal Problems 333-372, as submitted to and accepted for publication by the volume editor(s) on 11 June 2014.

It does not contain any later editorial amendments or corrections made during the proofing process. Please use for preliminary reference only and cite the final published version with the appropriate pagination.

developments, ${ }^{131}$ the Supreme Court's decision establishes authoritatively that mere 'causative ignorance' or 'inadvertence' does not amount to a mistake. ${ }^{132}$ As things stood before Pitt v Holt, there was a widespread tendency to conflate the mistake issue with the 'but for' test of causation. Brennan J's obiter statement to the effect that restitution should follow where a donor 'would not have paid the money had [he] known all the relevant circumstances, both legal and factual $^{133}$ may serve as an example. Now we know better. It is insufficient that the claimant would not have made the transfer had he been aware of a particular fact. This circumstance alone does not show us that he was mistaken. Put differently, the 'but for' test of causation does not tell us anything positive about a person's reasons for making a decision; it merely identifies the factors which would have tipped the balance against it. ${ }^{134}$

It is, of course, true that the line between causative ignorance and a genuine mistake can be terribly hard to draw (as the Pitt litigation itself demonstrates), ${ }^{135}$ and there is something in the argument that the most fundamental issues are often those to which people give the least thought. ${ }^{136}$ Nevertheless, since the demarcation has now been laid down, we must try to make it work and exploit its strengths. One such strength is that the newly refined concept of mistake actually helps us dispose of a number of the more unsavoury gift hypotheticals discussed in the literature (such as that of the homophobe uncle who wants to recover a gift from his nephew

${ }^{131}$ Pitt v Holt (SC) (n 1) [104], [109]-[113], drawing on W Seah, 'Mispredictions, Mistakes and the Law of Unjust Enrichment' [2007] RLR 93. Lord Walker described Ogden v Trustees of the RHS Griffiths 2003 Settlement (n 12), where the donor wrongly believed that he had a fair chance of surviving for at least another seven years (after which the transfer would have been tax-free, see n 77 and text thereto), as a case on the boundary between mistake and misprediction, ultimately turning on no more than 'a hair's breadth finding' of fact (at [113]).

132 Pitt v Holt (SC) (n 1) [104]-[108]. Lord Walker was careful to emphasize (at [105]) that although '[f]orgetfulness, inadvertence or ignorance is not, as such, a mistake, ... it can lead to a false belief or assumption which the law will recognize as a mistake', and he referred to Lady Hood of Avalon v Mackinnon (n 31) as an example. Cf also Seah (n 131) 95-99; D Sheehan, 'What is a Mistake?' (2000) 20 LS 538, 539-45.

133 The quote is from David Securities v Commonwealth Bank of Australia (n 9). See n 10 and text thereto.

134 Similar T Honoré, 'Necessary and Sufficient Conditions in Tort Law' in DG Owen (ed), Philosophical Foundations of Tort Law (Clarendon Press 1995, reprinted 2003) 363, 384: 'But-for reasons are often not reasons for making a decision or acting on it, but are reasons against not making it.'

135 See text to notes 24-27. The difficulty of drawing the line is the reason why the editors of Goff \& Jones (n 91) paras 9-40 to 9-42, having weighed up the various pros and cons, ultimately reject it.

${ }^{136}$ I would like to thank Professor Wolfgang Schön for discussing this conundrum with me. 
Note: This is the manuscript of an article published in (2014) 67 Current Legal Problems 333-372, as submitted to and accepted for publication by the volume editor(s) on 11 June 2014.

It does not contain any later editorial amendments or corrections made during the proofing process. Please use for preliminary reference only and cite the final published version with the appropriate pagination.

when he finds out that his nephew is gay, having never before considered the nephew's sexual orientation). ${ }^{137}$

Pitt $v$ Holt makes clear that although erroneous data do not necessarily have to be actively on a person's mind to amount to a mistake ('incorrect conscious belief'), they do have to feature somewhere in the background. Drawing on the terminology used in the new edition of Goff \& Jones, ${ }^{138}$ Lord Walker described this as an 'incorrect tacit assumption'. ${ }^{139}$ It is just conceivable that, once fleshed out, the distinction between 'causative ignorance' and mistaken 'tacit assumptions' will yield a test similar to the 'officious bystander' test in contract law. ${ }^{140}$ If the donor, asked at the moment of transfer whether he assumes a certain state of affairs to be true, would immediately have replied 'of course', then we are dealing with a tacit assumption, otherwise with legally irrelevant ignorance or inadvertence.

The second aspect of making a genuine mistake is an evidential one. Here we are left to read much between the lines of Pitt v Holt. The impression one gets is that the Supreme Court considered the combined 'seriousness' and 'unconscionability' test helpful in weeding out fabricated mistakes, ie cases where a person merely claims to have made a mistake in order to recover a gift they subsequently regret making. Judicial discretion is, of course, a nice practical way of tackling this concern. The more unlikely a story sounds, and the more unreasonable is the motive asserted, the more readily a court can hold that the alleged mistake was insufficiently

${ }^{137}$ This example is given by P Birks, Unjust Enrichment (2nd edn, OUP 2005) 149-50, who suggests adopting an 'actively in the mind' test.

${ }^{138}$ See Goff \& Jones (n 91) paras 9-32 to 9-42.

${ }^{139}$ Pitt v Holt (SC) (n 1) [108]. It may be interesting to learn that German law is faced with the same issue in the context of $\S 2078$ BGB, the provision allowing rescission of testamentary dispositions induced by mistake (see $\mathrm{n}$ 113). The Federal Supreme Court's test is not dissimilar to Lord Walker's. The Court also regards mere causative ignorance as insufficient. It initially required what it called a 'subconscious assumption' ('unbewusste Vorstellung') on the part of the donor: BGH (16.3.1983) IVa ZR 216/81, FamRZ (Zeitschrift für das gesamte Familienrecht) 1983, 898. Now the Court prefers to speak of an assumption which the person concerned treats as self-evident ('selbstverständliche Vorstellung'): BGH (27.5.1987) IVa ZR 30/86, NJW-RR (Neue Juristische Wochenschrift: Rechtsprechungs-Report) 1987, 1412.

${ }^{140}$ See Southern Foundries (1926) Ltd v Shirlaw [1939] 2 KB 206 (CA) 227, affirmed [1940] AC 701 (HL), where MacKinnon LJ said: 'Prima facie that which in any contract is left to be implied and need not be expressed is something so obvious that it goes without saying; so that, if, while the parties were making their bargain, an officious bystander were to suggest some express provision for it in their agreement, they would testily suppress him with a common "Oh, of course!".' 
'grave' from an objective point of view, without having to suggest that a claimant is lying or has failed to prove the facts.

However, the problem of fabricated mistakes is not peculiar to gifts, even if the gift context may be particularly vulnerable. Why not accept that gift-givers are free to pursue their own subjective idiosyncrasies when bestowing gratuitous benefits on others and simply apply the normal evidential hurdles in the ordinary way? The more unlikely or unusual a motive, the more evidence will typically be required to persuade the court that a genuine mistake has occurred and that it caused the transfer to be made. ${ }^{141}$ And although a mistake does not have to be shared by, or even be known to, the other party in order to warrant relief, ${ }^{142}$ in practice a restitutionary claim will be easier to get off the ground if the donor has disclosed his reasons for making the gift and any relevant background assumptions at the outset. ${ }^{143}$

\section{Disregarding ‘Objectionable’ Motives}

The next concern emerging from Pitt $v$ Holt is that certain mistakes should not count because there is something objectionable about relying on them. This came up in connection with the Revenue's argument that relief should never be granted where the claimant's mistake was purely one of tax law. ${ }^{144}$ A legal system could adopt such a sweeping position if it wished, but Lord Walker drew a subtle and, it is submitted, preferable distinction. He stressed that a mistake about tax law is prima facie an ordinary mistake whose consequences for the donor fall to be assessed in accordance with the criteria applying to all mistakes of fact or law. ${ }^{145} \mathrm{He}$ then contrasted Pitt v Holt with Futter v Futter, the case with which Pitt v Holt was consolidated on appeal, but where mistake had not been pleaded in time. Whereas it would have been entirely

${ }^{141}$ A person claiming that they had only made a donation to the Red Cross because they thought that the mayor and vicar had also done so (see the example in $\mathrm{n} 83$ ) would need convincing proof to substantiate this claim.

${ }^{142}$ Pitt v Holt (SC) (n 1) [114].

${ }^{143}$ In the New Zealand Case of University of Canterbury $v$ Attorney-General (n 12), for example, the donor had always made clear that his purpose in making the gift was to increase the funds available to maintain a particular scholarship programme.

${ }^{144}$ See Pitt v Holt (SC) (n 1) [129].

145 ibid [130], referring to Deutsche Morgan Grenfell v IRC (n 14) [44], [133], [140]. In Pitt v Holt (at [132]), he described the Revenue's suggestion to withhold relief for mistakes relating exclusively to tax as 'much too wide, and unsupported by principle and authority'. 
legitimate, and indeed positively desirable, for the Pitts to have availed themselves of the tax break provided by statute, ${ }^{146}$ Lord Walker said of the parallel case:

Had mistake been raised in Futter there would have been an issue of some importance as to whether the Court should assist in extricating claimants from a tax-avoidance scheme which had gone wrong. The scheme adopted by Mr Futter was by no means at the extreme of artificiality (...) but it was hardly an exercise in good citizenship. ${ }^{147}$

He continued with the following more general observation:

In some cases of artificial tax avoidance the court might think it right to refuse relief, either on the ground that such claimants, acting on supposedly expert advice, must be taken to have accepted the risk that the scheme would prove ineffective, or on the ground that discretionary relief should be refused on grounds of public policy. ${ }^{148}$

As regards the latter ground, however, it is not obvious why we should need a discretionary regime operating a 'gravity' and 'conscience' test in order to refuse relief. Relief (in whatever form) could just as easily be denied under the causative mistake test as established in Barclays Bank v Simms. The causative mistake test does not force us to disregard public policy considerations. Quite the contrary is true. Some mistakes cannot count because recognizing them would undermine the unity and coherence of the legal system. This is already evident from the framework set up by Robert Goff J in Simms itself. ${ }^{149}$ If a contract is in place, the only mistakes that warrant restitution are those that allow the contract to be set aside. Turning back to non-contractual transfers, envisage a case where a widow makes a voluntary payment to a person who she thinks murdered her husband (a gift to reward crime, so to speak), and it turns out that no murder was committed or that the murderer was someone other than the donee. Surely there would be no question of restitution, however genuine or serious the widow's mistake may have been. Public policy alone dictates this result.

\footnotetext{
${ }^{146}$ Pitt v Holt (SC) (n 1) [134]

147 ibid [135].

148 ibid.

${ }^{149}$ See text to $\mathrm{n} 6$.
} 
Note: This is the manuscript of an article published in (2014) 67 Current Legal Problems 333-372, as submitted to and accepted for publication by the volume editor(s) on 11 June 2014.

It does not contain any later editorial amendments or corrections made during the proofing process. Please use for preliminary reference only and cite the final published version with the appropriate pagination.

As a general rule of thumb, we could say that a mistake concerning the donor's reasons for making a gift does not qualify for relief if the motive itself could not have been validly turned into either an express condition for the gift or into a ground for reserving a right of revocation. ${ }^{150} \mathrm{~A}$ donor must not be allowed to achieve by the back door what he cannot achieve directly. Sometimes the law refuses to countenance the motive per se (as in the supposed murder example), sometimes it forbids people pursuing certain aims in specified circumstances, ${ }^{151}$ and sometimes it feels constrained to disregard the purpose behind the gift in order to protect the donee from undue pressure. ${ }^{152}$ Tax avoidance (as opposed to legitimate tax planning) falls into the first category. A general anti-abuse rule (GAAR) has just been enacted. ${ }^{153}$ Its boundaries will in due course be thoroughly tested in litigation. The same boundaries should determine which mistaken donors can recover their gifts where a tax scheme fails and which donors must be denied the possibility of having a 'second bite at the tax avoidance cherry'. ${ }^{154}$ In this day and

${ }^{150}$ It is a rule of thumb only. There may be cases where the policy preventing an express condition or right of revocation being validly imposed does not apply in the same way to mistake-based restitutionary claims (see esp comment at the end of $\mathrm{n} 152$ ).

151 Though note that most anti-discrimination statues (like the Equality Act 2010) do not extend to the giftgiving context. Only a bold judicial stab at inferring some 'indirect effect' from the relevant legislation could prevent donors from openly flaunting their individual prejudices through express stipulations. Conversely, on the approach adopted here, mistakes relating to prejudicial motives should be deemed irrelevant no further than an express stipulation would be struck out.

152 There is, for example, a body of case law relating to conditional gifts made in restraint of marriage or intended to induce the donee to leave their spouse. Such conditions are generally treated as void. Professor Tang (n 43) 19-20 uses this as evidence to show that courts are already willing to protect the donee's personal autonomy and argues (at 20) that ' $[\mathrm{t}]$ he causal mistake approach, if applied to gifts, is equally if not more odious than such conditional gifts. At least the donee at the time a conditional gift was made knew the gift came with strings attached. Under the causal mistake approach, the donor is entitled to recall a gift based on unarticulated assumptions.' On the refined causal mistake test proposed here, however, the invalidity of the condition would prima facie translate over into the context of restitution for mistake and prevent the donor from recovering the gift. Yet it is worth considering whether the 'rule of thumb' should be disapplied where a mistake-based restitutionary claim could not actually expose the donee to the same pressure as an express condition or right of revocation might have done (particularly if the donee has already irreversibly committed herself to a specific course of conduct in ignorance of the donor's claim to restitution, so that the existence of the claim - the threat of its enforcement or prospect of a waiver - can no longer influence the decision-making process).

${ }^{153}$ Finance Act 2013, Part 5 (ss 206-215).

${ }^{154}$ W Henderson, 'Pitt v Holt [2013] UKSC 26: Setting aside a Voluntary Disposition for Mistake' [2013] Trusts and Trustees 1, 6. But cf also Ng (n 23) 575-76, describing Lord Walker's suggestion that tax avoiders may be barred from seeking restitution for mistake as a 'radical development' and pointing out that Parliament deliberately abstained from inserting a penalty provision into the statutory GAAR. N Lee, 'Futter $v$ HMRC; Pitt $v$ 
age, with tax avoidance high up on the political agenda, there is no reason why the ordinary causative mistake test should not be able to filter out certain tax mistakes in the same way as it filters out other mistakes relating to legally unacceptable motives.

\section{Taking Change of Position Seriously}

As we move from suggested refinements concerning the claimant's position under the causative mistake test to consider the defendant's side of things, we should remind ourselves that Lord Walker in Pitt v Holt apparently regarded the donee's reliance on the security of his receipt as something which the court will take into account when exercising its discretion. ${ }^{155}$ For others, like Professor Tang, whose seriousness criterion does not incorporate any discretionary element, ${ }^{156}$ the perceived inadequacies of the change of position defence in dealing with acts of emotional and similar non-disenriching reliance are among the main reasons why the hurdle for recovering mistakes gifts ought to be raised. ${ }^{157}$ Since the currency of the 'moral economy' (in which gifts operate) is love and affection, not money, so the argument runs, a disenrichmentcentred defence offers insufficient protection to the donee. ${ }^{158}$

From the perspective of the present paper, the answer to this concern falls into two parts. One is simply that we dish out love and affection at our own risk. We may be disappointed. If, out of gratitude or a sense of obligation, the donee has been particularly accommodating to the donor in non-monetary (social or emotional) terms, and it later transpires that the donor can recover his gift for mistake, that is not something the law can or should do anything about.

The second part of the answer lies in a better understanding, or possibly an adjustment, of the change of position defence itself. A strong argument can be made for the proposition that it is not merely a disenrichment defence intended to prevent the defendant from being

HMRC: The Rule in Hastings-Bass and of Mistake Reviewed' [2014] Conv 175, 184, criticizes that Lord Walker's criterion for denying relief is 'artificiality', while the statute is aimed as striking down only 'abusive' schemes.

155 See $n 72$ and text thereto.

${ }^{156}$ See text to 68 .

${ }^{157}$ Tang (n 43) 24.

158 ibid, where Tang gives the example of a man who makes an expensive gift of jewellery to a woman over dinner, thereby winning her heart. An atmosphere is created which leads the parties to make love later that night. 
financially worse off. ${ }^{159}$ Instead, as judges have begun to indicate, ${ }^{160}$ there are exceptional circumstances where the law should be able to recognize non-pecuniary changes of position (or changes of position that are practically impossible to quantify), particularly where the act of reliance is irreversible and barring the restitutionary claim is the only way to avert great hardship for the defendant. The case where a donee drops out of a degree programme or decides to have a baby in reliance on the gift may perhaps serve as an illustration. ${ }^{161}$ Interestingly, Robert Walker LJ himself (as he then was) had at one point favoured a 'wide view' of the change of position defence on the ground that this facilitated a more generous approach to restitution. ${ }^{162}$ There is no difference in kind here between the gift context and an ordinary mistaken payment scenario. The law of restitution as a whole would profit from catering for exceptional cases of non-disenriching reliance.

\section{Protecting Third Parties}

The final concern emerging from Pitt $v$ Holt relates to the protection of third parties. This is an issue that really only arises where the claimant seeks a proprietary remedy, typically in order to

${ }^{159}$ This view of the change of position defence has recently received an endorsement from the High Court of Australia in Australian Financial Services and Leasing Pty Ltd v Hills Industries Ltd [2014] HCA 14, esp [21]-[25], [77]-[93] and [143]-[158], drawing inter alia on the work of E Bant, The Change of Position Defence (Hart 2009), The decision, however, needs to be read and understood against the backdrop of the Australian equity jurisprudence with its preference for rationalizing unjust enrichment situations in terms of 'unconscionability'. It was handed down after the CLP lecture on which this paper is based had been delivered.

${ }^{160}$ Esp Munby J in Commerzbank AG v Price-Jones [2003] EWCA Civ 1664, [65]-[72], saying that whether or not it is possible to calculate the cost of a decision made by the enrichee in reliance on his receipt is 'a distinction without a difference' (at [66]). He referred to earlier comments made by Robert Walker LJ to the same effect. These are discussed below, in $\mathrm{n} 162$ and the text thereto.

161 The latter is a variation of an example given by Birks (n 137) 260, who sees such a non-disenriching change of position as an 'unjust-related defence' (discussed at 209, 258-61). Even apart from the question of recognizing non-pecuniary detriment, the law has long struggled to put a price-tag on the having and bringing up of a child, as the so-called 'wrongful birth' cases show.

162 Scottish Equitable plc v Derby [2001] EWCA Civ 369, [2001] 3 All ER 818, [30]-[32], where Robert Walker LJ observed that ' $[\mathrm{t}]$ he fact that the recipient may have suffered some misfortune (such as a breakdown in his health, or the loss of his job) is not a defence unless the misfortune is causally linked ... with the mistaken receipt' (emphasis added). As the 'most obvious example' of a 'decision which involves no immediate expenditure, but is nevertheless causally linked to the receipt' he referred to a defendant enrichee 'voluntarily giving up his job, at an age when it would not be easy to get new employment'. Because such a decision involves an element of reliance (as opposed to other forms of causality), he suggested that this counted as a relevant change of position 'even on the narrow view as to the scope of the defence'. 
recover in specie what he has given away or in order to gain 'priority' in the defendant's insolvency. Adequate third party protection is undeniably of prime importance in this context. In Pitt $v$ Holt, it seems to have played a role that Mrs Pitt had given an irrevocable undertaking to the effect that she would not bring any claim against third parties, such as the recipients of distributions or of other payments from the trustees. ${ }^{163}$ Lord Walker indicated that the Court might otherwise have required such an assurance before granting relief. ${ }^{164}$

Yet it seems unwieldy and indeed out-of-place to factor the problem of third party protection into a discretionary test looking at the 'seriousness' of the claimant's mistake and the state of the defendant's 'conscience'. Nor is it wholly convincing to argue, as Sir Terence Etherton does, that the potential effect on third parties justifies making proprietary relief by way of equitable rescission more difficult to obtain than a personal common law remedy. ${ }^{165}$ There are tried and tested mechanisms by which third parties can be shielded from the adverse consequences of proprietary restitution between donor and donee if and when the need arises. The established rules on bona fide purchase do just that.

Moreover, as suggested earlier, within the realm of proprietary restitution, it is unnecessary to distinguish between the 'Pitt $v$ Holt equitable right to rescission' and forms of 'proprietary relief for a common law claim in unjust enrichment'. ${ }^{166}$ There is actually an approach which allows us to align cases like Pitt $v$ Holt with cases like Chase Manhattan, ${ }^{167}$ and which at the same time ensures adequate third party protection. It is the so-called 'power model' of proprietary restitution. ${ }^{168}$ According to the power model, whether we are dealing with a mistaken double payer like the claimant bank in Chase Manhattan or with a mistaken donor like John Smith in the necklace example, the analysis is the same. Both transferors have a choice of bringing either a personal claim to recover the value of what they have transferred, leaving the transfer of property as such in place, or they can exercise an equitable power in rem in order to

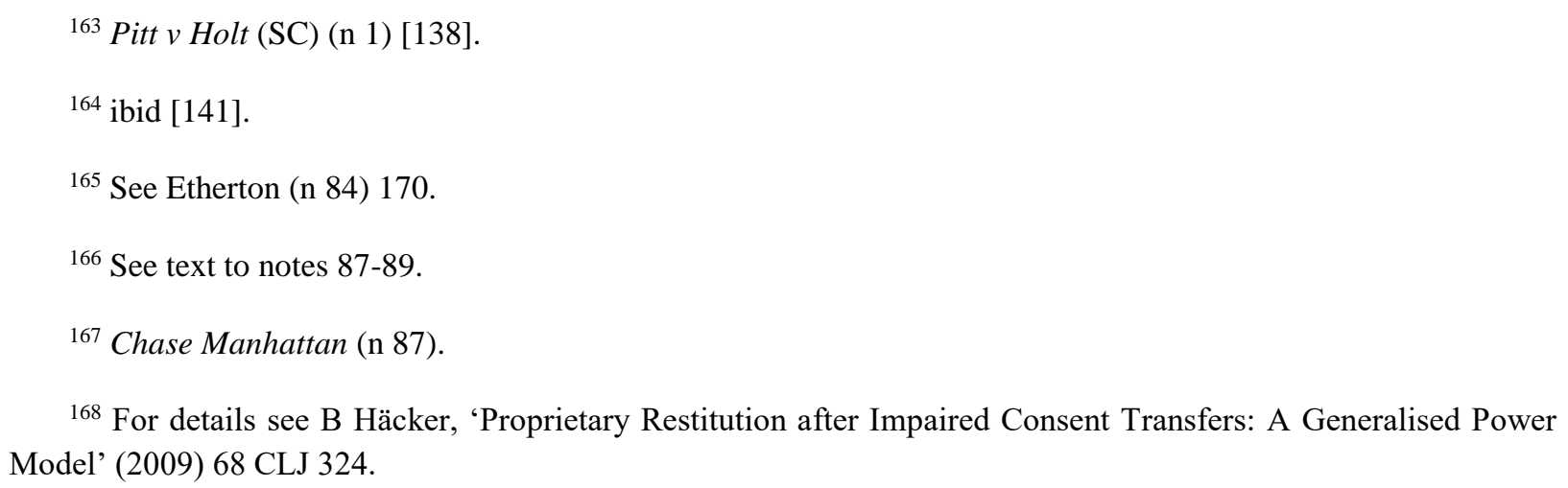


avoid the transfer of property, thereby bringing a resulting trust into existence. ${ }^{169}$ Where the impugned conveyance was an informal one, it is debatable whether the exercise of such an equitable power in rem is an act of self-help 'rescission' or requires a court order, ${ }^{170}$ but in the light of Lord Browne-Wilkinson's comments on Chase Manhattan in Westdeutsche Landesbank Girozentrale $v$ Islington $L B C,{ }^{171}$ the preferable view is that the claimant merely needs to notify the recipient of his intention to avoid the transfer. Once notified, the latter's 'conscience' may be said to be affected, if one wants to continue using this type of terminology.

There are, of course, a variety of views on proprietary restitution competing with the power model outlined here. Some people maintain that unjust enrichment as an event should on principle never generate a proprietary response, ${ }^{172}$ others argue that no less than a fully-fledged trust can come into existence from the moment of receipt. ${ }^{173}$ If one was sceptical about giving proprietary restitution too wide a scope, one might think of confining it to cases of induced mistake, leaving the claimant with only the personal remedy where his mistake was spontaneous. ${ }^{174}$ But quite irrespective of the merits of the power model or its range, the point is that proprietary restitution as a whole needs sorting out, and it would be helpful if the law on mistaken gifts after Pitt $v$ Holt was fitted into the broader general framework rather than being relegated to an island of its own.

${ }^{169}$ A common law power in rem to 'pull back' legal title exists only in fraud cases: Car \& Universal Finance Co Ltd v Caldwell [1963] EWCA Civ 4, [1965] 1 QB 525.

${ }^{170}$ See $\mathrm{n} 74$ and text thereto.

171 See Westdeutsche Landesbank (n 88) 715, where Lord Browne-Wilkinson said that although he did not accept Goulding J's reasoning in Chase Manhattan (in terms of the mistaken payer 'retaining' an equitable interest in the money transferred), the decision could be justified by the fact that the defendant bank had been notified of the clerical error within two days of receiving the payment: 'Although the mere receipt of the moneys, in ignorance of the mistake, gives rise to no trust, the retention of the moneys after the recipient bank learned of the mistake may well have given rise to a constructive trust.'

${ }^{172}$ See eg W Swadling, 'Property and Unjust Enrichment' in JW Harris (ed), Property Problems: From Genes to Pension Funds (Kluwer 1997) 130.

173 See eg R Chambers, Resulting Trusts (OUP 1997) esp 11-39, 111-42, 171-84. Note, however, that Chambers has since refined his view. He now regards 'gift' as a transaction akin to contract and argues that a fullyfledged trust is inappropriate prior to rescission: R Chambers, An Introduction to Property Law in Australia (3rd edn, Lawbook Co 2013) ch 24, paras 24-10, 24-70, and 24-140.

174 See the discussion in Häcker (n 168) 354-57. 
Note: This is the manuscript of an article published in (2014) 67 Current Legal Problems 333-372, as submitted to and accepted for publication by the volume editor(s) on 11 June 2014.

It does not contain any later editorial amendments or corrections made during the proofing process. Please use for preliminary reference only and cite the final published version with the appropriate pagination.

\section{A Word on Deeds}

Before concluding, a word needs to be said on formal gifts made by deed. There are certain special features about deeds which the law has to take into account. The most obvious is that a court order seems indispensable where a deed is to be set aside, at least in equity. ${ }^{175} \mathrm{~A}$ formal instrument has been brought into being which subsists until it is avoided by a competent body. The formality involved in deeds has prompted even authors who are generally in favour of a causative mistake test for gifts to toy with the idea that Pitt $v$ Holt establishes a 'hierarchy' of restitutionary hurdles, according to which a 'serious mistake' test now applies specifically to dispositions by deed. ${ }^{176}$

However, it is unnecessary to go so far. The peculiarities of gifts made by deed can be accommodated without sacrificing the causative mistake test. To understand what refinements are inevitable, we need to bear two things in mind. One is that it is possible to rectify a deed where the party executing it has made a mistake about its contents. ${ }^{177}$ Rectification relates to the words used in a formal instrument and effectively adjusts the written document to what it was intended to 'say'. In the case of a gratuitous transaction such as a deed of gift, even unilateral spontaneous mistakes count. ${ }^{178}$ If the donor's mistake is of the relevant kind, ${ }^{179}$ then rectification rather than 'rescission' is the appropriate remedy for him to seek. ${ }^{180}$

175 This appears to be wholly uncontroversial, probably due to the fact that the rescission of a transaction under seal and a court order for cancellation of the deed which embodies it have long gone hand-in-hand: cf O'Sullivan et al, Law of Rescission (n 74) paras 29.81-29.84.

176 Davies and Virgo (n 23) 83-84, who go on to question critically whether the appropriate test of mistake should really 'depend on the potential accident of whether a gift is made by deed or bank transfer'. See also Watterson (n 40) 503-4.

${ }^{177}$ This is to be distinguished from the situation where the deed is a forgery, has otherwise been tampered with, or where the person executing it cannot understand its significance at all. In such cases, the plea of non est factum marks the deed out as void.

${ }^{178}$ Re Butlin's Settlement Trusts [1976] Ch 251 (Ch D), concerning a voluntary settlement, is the leading case.

${ }^{179}$ See ibid 260, where Brightman J defined the scope of the remedy as follows: '[R]ectification is available not only in a case where particular words have been added, omitted or wrongly written as the result of careless copying or the like. It is also available where the words of the document were purposely used but it was mistakenly considered that they bore a different meaning from their correct meaning as a matter of true construction. In such a case ... the court will rectify the wording of the document so that it expresses the true intention.'

180 Rather worryingly, judges have recently begun to suggest that the Pitt $v$ Holt criteria for equitable intervention in rescission cases (ie sufficient 'gravity' of the mistake and 'unconscionability') will in future also apply to the rectification of voluntary instruments. See Day v Day (n 53) esp [38]-[45], decided before the Supreme 
The other thing to remember about deeds is that they can have both obligatory and proprietary effects under English law. They may therefore be employed in different ways by a person intending to bestow a gratuitous benefit on another. Two main scenarios arise. We will consider them in turn.

In the first, the deed is used to make a gratuitous promise enforceable. The 'donor' wishes to be bound before he can actually perfect the gift. When he later effects the promised transfer, ${ }^{181}$ he is fulfilling an existing obligation. The deed vehicle here acts as a substitute for contractual consideration. It may be that this realization is what had prompted the Revenue to maintain at one point in Pitt $v$ Holt that a voluntary deed could only be set aside for mistakes of a kind which would render a contract void (or, one might add, voidable). ${ }^{182}$ However, since the doctrine of consideration is not merely about making promises enforceable, but actually helps us distinguish more generally between reciprocal bargains and non-bargain transactions, Lord Walker quite rightly gave their 'heterodox submission' short shrift. ${ }^{183}$ In truth, the only special feature about this first situation is that a mistake-based claim to recover the gift or its value cannot succeed before the deed of promise has been avoided. So if, for example, the gift was of money, the claimant's personal action for money had and received depends on a court declaring the promissory deed invalid beforehand.

The second scenario is where the deed is used as an instrument of conveyance. ${ }^{184}$ Instead of making an informal gift by simple delivery, the donor executes a deed to effect the transfer. ${ }^{185}$

Court decision in Pitt $v$ Holt had been handed down, where Lewison LJ regarded it as 'clear ... that rectification and rescission are to be treated in the same way, depending on the facts'(at [41]). While the effects/consequences distinction from Gibbon $v$ Mitchell (n 20), which was arguably an illegitimate transplant from rectification into the rescission context (see n 66), has just been rejected by the Supreme Court, it may ironically be that the line is now becoming blurred from the other side, with rectification being infiltrated by elements of rescission doctrine.

${ }^{181}$ For the sake of simplicity, we will assume that the transfer itself is an informal one (eg the payment of money).

${ }^{182}$ Pitt v Holt (SC) (n 1) [115].

183 ibid, remarking that 'the notion that any voluntary disposition should be accorded the same protection as a commercial bargain, simply because it is made under seal, is insupportable'.

${ }^{184}$ Without a preceding promise under seal: $\mathrm{cf}$ n 181.

${ }^{185} \mathrm{He}$ may do this because a particular chattel is unwieldy or not in his possession (so that a physical delivery or one of the recognized substitutes might be problematic) or because he wants to give away realty (where a deed is always required). 
Here, the relevance of the deed for the current inquiry lies primarily in the realm of proprietary restitution. ${ }^{186}$ If one thinks that 'equitable rescission' always requires a court order whatever form the gift took, nothing changes. On the view advanced above, ${ }^{187}$ however, the 'conveyance by deed' scenario differs from the 'informal gift by delivery' scenario in that the mistaken donor's power to avoid the transfer can now only be exercised with the help of the court. Yet it is hard to see why in principle the court should apply stricter (or otherwise divergent) standards to proprietary restitution of gifts made by deed than govern informal gifts.

\section{Conclusion}

Pitt $v$ Holt has brought English law to a real junction as far as the treatment of mistaken gifts is concerned. It reveals that there is not yet a fully settled understanding of what a 'gift' is, nor about how the historically determined remedies at common law and in equity interact outside the contractual sphere. Although we tend to think of these remedies as well-established, their genesis leaves part of the field uncovered and leads to inconsistencies in other areas. The shimmering concept of 'rescission', in particular, imports a latent ambiguity between the idea of a gift being a special type of non-bargain transaction and the purely proprietary aspect of making a gratuitous transfer. It is thus unsurprising that Pitt $v$ Holt should be open to various interpretations. Future judges will have to decide whether the Supreme Court's decision means that there is now, or perhaps always has been, a distinct law of gifts with special rules about when and how they may be recovered.

The argument made here was that it would be better to try to integrate the law relating to mistaken gifts into the existing framework of the law of restitution for unjust enrichment and at the same time use Pitt $v$ Holt as an occasion for reviewing and rationalizing the whole area. In order to recover, a mistaken donor should have to overcome not three hurdles (as the Court of Appeal thought), nor two hurdles (as the test formulated by the Supreme Court suggests), but just one hurdle. That single hurdle is the causative mistake test, properly handled and

${ }^{186}$ Unless one regards the deed as having obligatory as well as proprietary consequences, it should be possible to bring a personal mistake-based claim for the value of the gift without having to impugn the deed of conveyance itself.

${ }^{187}$ See text to notes 170 and 171. 
Note: This is the manuscript of an article published in (2014) 67 Current Legal Problems 333-372, as submitted to and accepted for publication by the volume editor(s) on 11 June 2014.

It does not contain any later editorial amendments or corrections made during the proofing process. Please use for preliminary reference only and cite the final published version with the appropriate pagination.

appropriately refined. Once it becomes clear that the ordinary law of the land can already cater for the concerns which appear to lie at the heart of the discretionary approach adopted in Pitt $v$ Holt, it may be hoped that the Supreme Court will be prompted to speak again in order to finally jettison the language of 'seriousness' and 'unconscionability'. 